Document downloaded from:

http://hdl.handle.net/10251/64019

This paper must be cited as:

Moreno Marro, O.; Atarés Huerta, LM.; Chiralt A. (2015). Effect of the incorporation of antimicrobial/antioxidant proteins on the properties of potato starch films. Carbohydrate Polymers. 133:353-364. doi:10.1016/j.carbpol.2015.07.047.

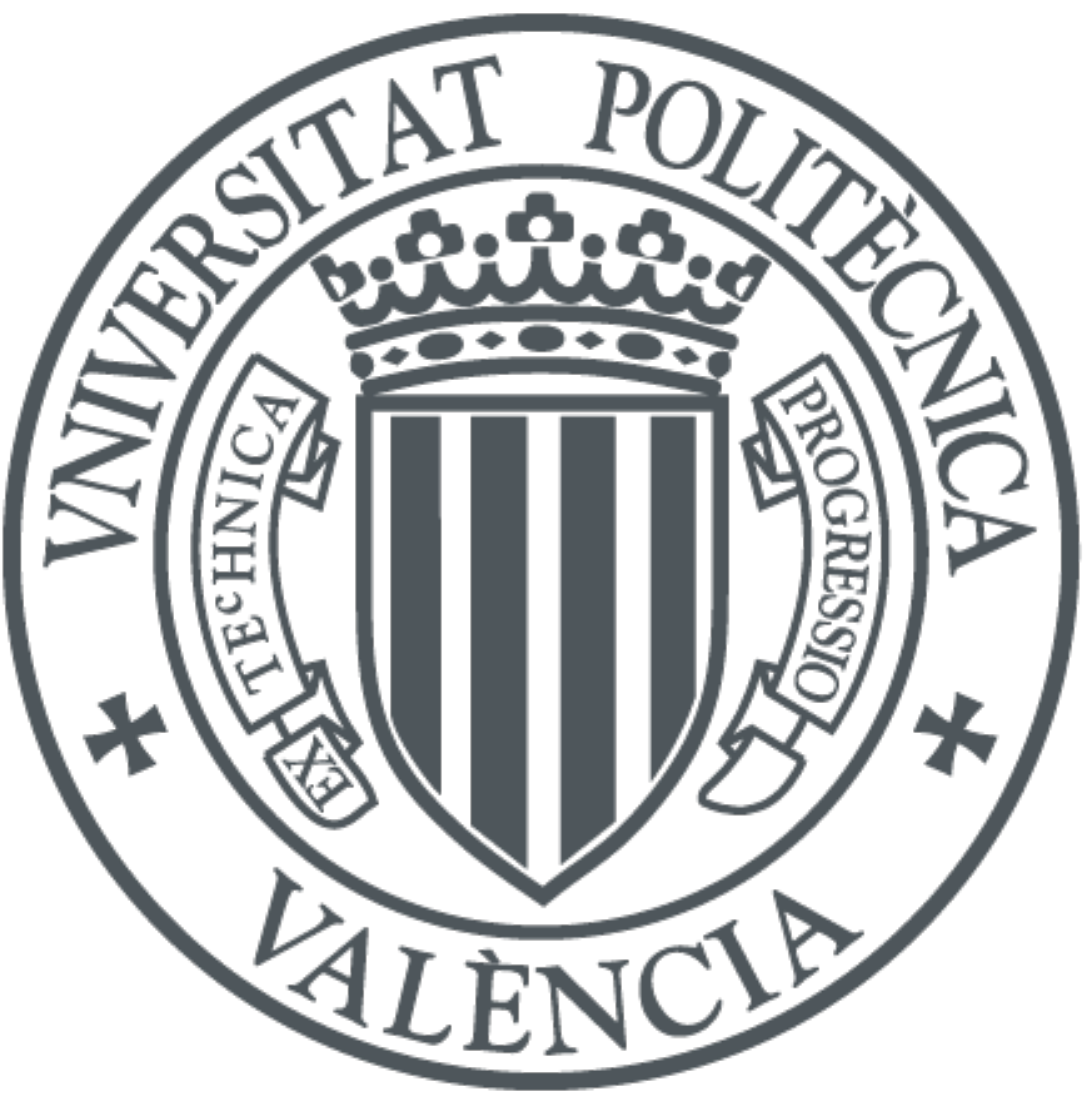

The final publication is available at

https://dx.doi.org/10.1016/j.jfoodeng.2014.05.015

Copyright Elsevier

Additional Information 


\section{Effect of the incorporation of antimicrobial/antioxidant proteins on the properties of potato starch films}

Olga Moreno*, Lorena Atarés, Amparo Chiralt

Departamento de Tecnología de Alimentos - Instituto de Ingeniería de Alimentos para el Desarrollo. Universitat Politècnica de València, Camino de Vera s/n 46022 Valencia, Spain.

Abstract:

Glycerol plasticized potato starch films containing bioactive proteins (lactoferrin (LF) and/or lysozyme (LZ), at 0.1 and 0.2 ratio with respect to starch) were obtained by casting method and characterised as to their microstructural, thermal and physical (water content, mechanical, water and oxygen barrier, optical) properties. The bioactive properties, named antioxidant and antimicrobial, of the proteins and the films were also characterized. The incorporation of proteins affected the structural and physical properties of potato starch films, while modifying their thermal behaviour and increasing the glass transition temperature. Both proteins showed a certain degree of compatibility with starch chains through the bond formations (increase in $\mathrm{Tg}$ ), while a part is separated and migrates to the film surface. Their incorporation, especially that of lactoferrin, greatly increased the film's brittleness, regardless of the films water content, although they enhance the water vapour and oxygen barrier properties, whatever the age of the film. Protein also reduced the film's transparency and gloss, while lactoferrin induced colour changes. The thermal degradation of blend films and isolated proteins occurred at temperatures of over $250^{\circ} \mathrm{C}$, which means that blend starch films can be thermoprocessed, according to their thermoplastic properties and following the usual practices of the plastics industries. A synergistic antimicrobial action against E.coli and coliforms was observed when both LZ and LF were simultaneously applied. Both of these exhibited antioxidant capacity.

Keywords: edible films, potato starch, lactoferrin, lysozyme, bioactive properties. 


\section{Introduction}

Nowadays, the accumulation of non-biodegradable plastics is a paramount environmental concern which still has not been efficiently addressed (Azeredo, 2009). Bioplastics produced from renewable resources are being recognized as a solution to environmental problems concerning waste and dependence on fossil fuels (Byun \& Kim, 2014). Starch is one of the most widely used and promising materials in the bioplastics market due to its biodegradability, availability, renewability and low cost (Wilhelm et al., 2003; Barnett, 2011). Native starch does not have thermoplastic properties; however, with the addition of plasticizers and thermal-shearing processing, native starch gelatinizes and turns into thermoplastic starch (TPS), from which films can be obtained by using both solution casting or thermoprocessing (Zhang et al., 2014).

Biodegradable packaging materials can additionally be carriers of antioxidant and/or antimicrobial agents (Sánchez-García et al., 2008) in order to obtain active packaging products, in which active compounds are released into the food or the surrounding environment (e.g. head space) in the package so as to extend the shelf life of food and to improve its safety and quality properties (Realini \& Marcos, 2014).

Oxidation is a chemical process, slower than microbial spoilage, which lies in a primary quality factor limiting the shelf-life of a wide variety of foods, mainly dry and/or fatty foods. With the aim of avoiding the oxidation damage, edible films and coatings can be used as oxygen barrier layer and vehicle for antioxidant delivery. A trend towards using natural antioxidants instead of synthetic ones exists due to consumer perceptions of the safety and acceptance of such antioxidants compared to synthetics (Lee, 2014). Edible films containing natural antioxidants have been extensively applied to fresh products and dried foods (Das et al., 2013; Gimenez et al., 2011; Han et al., 2008; Lin et al., 2008).

As regards microbial spoilage, the growth of microorganisms is not only detrimental to the organoleptic characteristics of food (such as off-odors and accelerated changes in aroma, color and texture), but also some microorganisms and their toxins may cause food recalls and serious foodborne outbreaks (Corrales et al., 2014). In order to prolong the food shelf-life and maintain product safety, quality and freshness, it is necessary to select adequate materials and packaging technologies, of which biodegradable films containing antimicrobials are being extensively studied (Kechichian et al., 2010). The incorporation of active compounds into food packaging increases the efficiency of food preservation (Moreno et al., 2014). Likewise, the use of natural antimicrobials is gradually growing because of the greater consumer awareness of the potential health risks of some synthetic antimicrobials (Gyawali \& Ibrahim, 2014; Moreira et al., 2005).

Lactoferrin and lysozyme could be used for the purposes of conferring active properties to biodegradable films (Jenssen and Hancock, 2009). Lactoferrin (LF) is an iron-binding glycoprotein (approximately $80 \mathrm{KDa}$ ), belonging to the family of transferrin proteins (Farnaud and Evans, 2003; García-Montoya et al., 2012; Jenssen and Hancock, 2009; Pan et al., 2007), which has been reported as an antimicrobial enzyme against a wide array of Gram positive and Gram negative bacteria (Drago, 
2006; Pan et al., 2007). The antibacterial action of LF is based on both bacteriostatic and bactericidal mechanisms. The bacteriostatic effect is due to its ability to sequestrate iron making this nutrient unavailable for bacteria (Arnold et al., 1977; Reyes et al., 2005). The bactericidal effect has been attributed to its direct interaction with the bacterial membranes (Garcia-Montoya et al., 2012). Specifically, LF has the ability to damage the outer membrane of Gram-negative bacteria directly due to its interaction with lipolisacharide (LPS) (Ellison et al., 1988). The use of Lysozyme (LZ) in antimicrobial packaging applications has been described by several authors (Barbiroli et al., 2012; Gemili et al., 2009, Buonocore et al., 2005). The antimicrobial activity of this protein is based on its ability to break the bonds between $\mathrm{N}$-acetylmuramic acid and $\mathrm{N}$-acetylglucosamine of the peptidoglycan of the cell walls of Gram-positive bacteria (Guçbilmez et al., 2007). In order to amplify combining it with detergents and chelators which lead to the destabilization of the outer membrane in Gram-negative bacteria (Gill \& Holley, 2000; Branen \& Davidson, 2004). In this sense, LF has the ability to enhance the antibacterial activity of LZ, due to its interaction with the LPS (Garcia-Montoya et al., 2012; González-Chávez et al., 2009, Sung et al., 2013). Yamauchi (1992) observed a direct interaction between both proteins against Micrococcus luteus, while Suzuki et al. (1989) obtained a greater bacteriostatic effect when both proteins were used in combination. Recently, other authors (Barbiroli et al., 2012) have obtained similar results, reporting a synergistic action against Listeria.

As concerns the antioxidant activity, LF has been pointed out as an natural antioxidant protein (García-Montoya et al., 2012; Joubran et al., 2013; Samarasinghe et al., 2014; Stejins and Hooijdonk, 2000; Wakabayashi et al., 2006). Elias et al. (2008) reported that different alimentary proteins and peptides can interfere with radical reactions, acting as primary or secondary antioxidants. LF could act as a secondary or preventive antioxidant, due to its chelation capability of transition metals (e.g. iron and copper), which would retard the oxidation process (Huang et al., 2005). On the other hand, LZ has been reported as capable of suppressing the generation of reactive oxygen species (ROS) (Liu et al., 2006), which confers it with antioxidant activity.

In order to obtain active starch films with adequate functional properties, the effect of incorporating LF, LZ, and their blend, on the structural, thermal and physical properties of starch biodegradable films was analysed. To evaluate the active properties of the films, the antioxidant and antibacterial properties were analyzed in both pure LF and LZ, and their blend, and in the obtained films.

\section{Materials and methods}

\subsection{Raw materials}

Potato starch (PS) with $17.9 \%$ amylose content was supplied by Roquette Laisa Spain, S.A. (Lestrem cedex, France); lyophilized bovine lactoferrin (LF) was provided by ABIAL Tecnología e Innovación S.L. (Santander, Spain) and lysozyme (LZ) by DSM Food Specialties B.V. (Delft, Netherland). Glycerol, magnesium nitrate and phosphorus pentoxide were supplied by Panreac 
Química S.A. (Castellar de Vallès, Barcelona, Spain). Stock cultures, Escherichia coli (CECT 101) and Listeria innocua (CECT 910), employed for the antimicrobial activity analysis, were supplied by the Spanish Type Culture Collection (CECT, Burjassot, Spain). Tryptone Soy Broth, Agar bacteriological, Buffered peptone water, Plate Count Agar, Palcam Agar and Violet Red Bile Agar were provided by Scharlab, (Barcelona, Spain). NaCl was purchased from (Panreac, Barcelona, Spain). Acetic Acid glacial and Potassium lodide $(\mathrm{KI})$ were supplied by Panreac Química S.A. (Castellar de Vallès, Barcelona, Spain), lodine by Acros Organics (Geel, Belgium) and 1-Decanol by Alfa Aesar (Karlsruhe, Germany).

\subsection{Experimental design and film casting}

PS was dispersed in distilled water at $2 \%$ wt., using magnetic stirring for 5 to 10 minutes. These PS dispersions were heated in a thermostatic bath at $99^{\circ} \mathrm{C}$ for 30 minutes and stirred every 5 minutes. After cooling down with running water, glycerol was added (mass ratio of glycerol to PS was 0.25:1). The dispersions were homogenized with a rotor stator ultraturrax D125 for 4 minutes at 13,500 rpm, and finally were degassed at room temperature by means of a vacuum pump (MZ 2C NT, Vacuubrand GMBH + CO KG, Wertheim, Germany). Separately, protein (LF and/or LZ) aqueous dispersions at $10 \%$ wt. were prepared with magnetic stirring for 20 minutes and degassed. Finally, the PS-glycerol dispersion and the protein dispersions were mixed in different proportions through magnetic stirring and degassed. Seven different combinations of PS, LF and LZ were obtained, with 0.1 or $0.2 \mathrm{~g}$ protein per g PS. Net LZ or LF and 1:1 blend of both were used. Sample codes (two digits) indicate the $\mathrm{g}$ of LF and LZ per $g$ of PS.

Teflon plates $(150 \mathrm{~mm}$ diameter) were used for film casting. The mass of film forming dispersions corresponding to $1.5 \mathrm{~g}$ of solids was cast on each plate. After drying for $48 \mathrm{~h}$ at $45 \% \mathrm{RH}$ and $25^{\circ} \mathrm{C}$, the films were separated from the plates. For the purposes of studying the effect of storage time on the physical properties of the films, the samples were stored, at $25^{\circ} \mathrm{C}$, for 1 or 5 weeks prior to analyses in desiccators at $54 \% \mathrm{RH}$, by using an oversaturated $\mathrm{Mg}\left(\mathrm{NO}_{3}\right)_{2}$ solution. In order to assess the role of moisture content on the mechanical properties of the films, a part of the dried films was also conditioned, for 1 or 5 weeks, at $33 \% \mathrm{RH}$ and $25^{\circ} \mathrm{C}$, by using $\mathrm{MgCl}_{2}$ oversaturated solution.

\subsection{Microstructural characterization}

Cross-section and surface images of the films were obtained by Scanning Electron Microscopy (SEM) using a JEOL $®$ microscope, model JSM-5410. The film samples were previously stored in a desiccator with $\mathrm{P}_{2} \mathrm{O}_{5}$ in order to eliminate film moisture. Film stripes (5x2mm approximately) were cryofractured by immersion in liquid nitrogen and mounted on cupper stubs. After gold coating, the samples were observed using an accelerating voltage of $10 \mathrm{kV}$. 


\subsubsection{THERMOGRAVIMETRIC ANALYSIS (TGA)}

The thermal behaviour of the conditioned film samples at $54 \% \mathrm{RH}$ was analysed using a thermogravimetric analyzer (TGA/SDTA 851e, Mettler Toledo, Schwarzenbach, Switzerland). Approximately $3 \mathrm{mg}$ of film samples were gradually heated at $10^{\circ} \mathrm{C} / \mathrm{min}$ from room temperature to $600^{\circ} \mathrm{C}$, under nitrogen flow $(50 \mathrm{~mL} / \mathrm{min})$. The initial degradation temperature $\left(\mathrm{T}_{0}\right)$, i. e. the temperature at which $5 \%$ mass loss is registered, was recorded. The temperature at which the maximum degradation rate was observed $\left(T_{\max }\right)$, i.e. the temperature of the peak in the first derivative graphs, as well as the percentage of mass loss at the end of the test $\left(600^{\circ} \mathrm{C}\right)$, were also registered. Measurements were run in duplicate.

\subsubsection{DIFFERENTIAL SCANNING CALORIMETRY (DSC)}

Film samples were desiccated with $\mathrm{P}_{2} \mathrm{O}_{5}$ and submitted to DSC analyses. Approximately $10 \mathrm{mg}$ of sample were weighed and sealed into aluminium pans. An empty sample pan was used as reference. Aiming to determine the glass transition temperature of the samples $\left(T_{g}\right)$, a first heating scan was done between 0 and $160^{\circ} \mathrm{C}$ at $50^{\circ} \mathrm{C} / \mathrm{min}$ (in order to allow the removal of residual water), followed by a cooling scan to $0^{\circ} \mathrm{C}$ and a second heating scan to $200^{\circ} \mathrm{C}$ at $10^{\circ} \mathrm{C} / \mathrm{min}$. The tests were perfomed with a DSC (TA Instruments, model DSC1 STARe System, Mettler Toledo) with a $20 \mathrm{~mL} / \mathrm{min}$ nitrogen flow. Each sample was analysed in duplicate.

\subsection{Physical characterization}

\subsubsection{WATER CONTENT}

The moisture content of conditioned film samples (at 33 or $54 \% \mathrm{RH}$ ) was determined using a gravimetric method. Five samples per formulation were considered. Water was eliminated from the samples using a two-step process: they were firstly desiccated in a vacuum oven $\left(60^{\circ} \mathrm{C}-24 \mathrm{~h}\right)$, and secondly stored in desiccators with $\mathrm{P}_{2} \mathrm{O}_{5}$ until constant weight was reached. The results were expressed as $\mathrm{g}$ of water per $100 \mathrm{~g}$ of dry film.

\subsubsection{MECHANICAL PROPERTIES}

The mechanical behavior of the films was analyzed using a texture analyser (TA-XTplus, Stable Micro Systems, Surrey, United Kingdom) according to ASTM D882 (2001). Twelve film stripes (25.4 $\mathrm{mm}$ wide and $100 \mathrm{~mm}$ long) per formulation were tested. Thickness was measured in four positions along the stripe by means of a hand-held digital micrometer (Electronic Digital Micrometer, Comecta 

rate of $50 \mathrm{~mm} / \mathrm{min}$ until breaking. The elastic modulus (EM (MPa)), tensile strength at break (TS $(\mathrm{MPa}))$ and percentage of elongation at break (\%E) were determined from stress-Hencky strain curves, obtained from force-deformation data. Films conditioned at $33 \%$ and $53 \% \mathrm{RH}$ and $25^{\circ} \mathrm{C}$ for 1 and 5 weeks were characterized.

\subsubsection{WATER VAPOUR AND OXYGEN PERMEABILITIES}

The water vapour permeability (WVP) of the film samples was measured with a modification of the ASTM E96-95 (ASTM, 1995) gravimetric method, (McHugh et al., 1993) using Payne permeability cups (Elcometer SPRL, Hermelle/s Argenteau, Belgium) of $3.5 \mathrm{~cm}$ in diameter. Six round samples per formulation were cut, and the thickness was measured in six points per sample (Electronic Digital Micrometer, Comecta S.A., Barcelona, Spain). WVP was determined at $25^{\circ} \mathrm{C}$ and $53-100 \% \mathrm{RH}$ gradient, which was generated by using an oversaturated $\mathrm{Mg}\left(\mathrm{NO}_{3}\right)_{2}$ solution and pure water, respectively. The side of the film which was in contact with air during drying was oriented towards the gas phase at $53 \% \mathrm{RH}$. The cups were weighed every $1.5 \mathrm{~h}$, for $24 \mathrm{~h}$ with an analytical balance (ME36S Sartorius, Alemania). After the steady state was reached, the slope obtained from the weight loss vs. time was used to calculate WVP.

The oxygen permeability (OP) was measured following the standard method (ASTM D3985-05, 2005), by using an Oxtran System (Mocon, Minneapolis, USA). The measurements were obtained at $53 \% \mathrm{RH}$ using $50 \mathrm{~cm}^{2}$ film samples. Oxygen permeability was calculated by dividing the oxygen transmission rate (OTR) by the difference in oxygen partial pressure between the two sides of the film, and multiplying by the average film thickness. At least two replicates per formulation were made.

\subsubsection{OPTICAL PROPERTIES: TRANSPARENCY, COLOUR AND GLOSS}

A spectrocolorimeter (CM-3600d, Minolta Co., Tokyo, Japan) was used to obtain the infinite reflectance spectra of the film samples. Measurements were taken on black and white backgrounds. The internal transmittance $\left(\mathrm{T}_{i}\right)$ of the films was determined by applying the Kubelka-Munk theory (Hutchings, 1999) for multiple scattering to the reflection spectra, following the methodology described by Pastor et al. (2010). Six samples per formulation were analyzed, and three measurements per sample were taken. The measurements were performed on the side of the film in contact with air during drying.

CIE-L*a*b* coordinates: lightness $\left(\mathrm{Lab}^{*}\right)$, chrome $\left(\mathrm{C}_{a b}{ }^{*}\right)$ and hue $\left(\mathrm{h}_{a b}{ }^{*}\right)$ of the films were obtained from the surface reflectance spectra using D65 illuminant $/ 10^{\circ}$ observer. The whiteness index (WI) was also calculated according to Atarés et al. (2010).

The gloss was measured on the film side in contact with air during drying, at a $60^{\circ}$ incidence angle, according to the ASTM standard D-523 (ASTM, 1999), using a flat surface gloss meter (MultiGloss 268, Minolta Co., Tokyo, Japan). Ten replicates were obtained per formulation. All the results 
were expressed as gloss units, relative to a highly polished surface of black glass standard with a value near to 100 .

\subsection{Characterization of active properties.}

\subsubsection{Antimicrobial tests}

In order to evaluate the antimicrobial activity of the proteins in the films, stock cultures of Listeria innocua (CECT 910) and Escherichia coli (CECT 101) were used. These were kept frozen $\left(-18^{\circ} \mathrm{C}\right)$ in Tryptone Soy Broth (TSB), supplemented with $30 \%$ of glycerol. To regenerate each culture, a loopful was transferred into $10 \mathrm{~mL}$ of TSB, then the tube was incubated at $37^{\circ} \mathrm{C}$ overnight and $10 \mu \mathrm{L}$ were again transferred into $10 \mathrm{~mL}$ of TSB. The tube was kept at $37^{\circ} \mathrm{C}$ for $24 \mathrm{~h}$ to reach the exponential phase of growth.

\subsubsection{In vitro assays.}

The antimicrobial activity of the proteins was analysed following a modification of the method described by Kristo et al. (2008). Pure LF and LZ and their 1:1 wt. ratio blend were tested as to their antibacterial activity against Listeria innocua and Escherichia coli. Tryptone Soy Agar (TSA) with 3\% $\mathrm{NaCl}$ was used as a model solid food system (TSA-NaCl) (Sánchez-González et al., 2011). 10mL of TSA-NaCl were poured into sterile petri dishes and left to solidify. Bacteria cultures in exponential phase of growth were adequately diluted for the inoculation of the agar plates in order to obtain $10^{2}$ $\mathrm{CFU} / \mathrm{cm}^{2}$ target inoculum. At that point, $1 \mathrm{~mL}$ of protein dilution ( $L F, L Z$ or their blend) was poured into the agar and left to adsorb on the surface under sterile conditions. The protein dilutions were prepared in order to obtain the same surface solid density of protein as that contained in the films with $0,2 \mathrm{~g}$ of protein $/ \mathrm{g}$ of starch $\left(1.17 \mathrm{mg}\right.$ protein $\left./ \mathrm{cm}^{2}\right)$. Inoculated TSA-NaCl petri dishes without protein were used as inoculum control. Plates were then sealed with parafilm to avoid dehydratation and incubated at $10^{\circ} \mathrm{C}$ and $25^{\circ} \mathrm{C}$ for 24 hours. Then, the agar was aseptically removed from the petri dishes and placed in a sterile plastic bag with $90 \mathrm{~mL}$ of buffered peptone water. Homogenization was performed for 2 minutes in a Stomacher blender (Bag Mixer 400, Interscience). Then, serial dilutions were made and poured onto the specific culture media for L.innocua and E.coli, Palcam Agar and Violet Red Bile Agar, respectively. Plates were incubated at $37^{\circ} \mathrm{C}$ for $48 \mathrm{~h}$ before colonies were counted. All the tests were run in triplicate.

The same method was used to analyze the antimicrobial activity of the films containing the active proteins $(0,2 \mathrm{~g} / \mathrm{g}$ of starch; film samples: $0.2-0 ; 0-0.2 ; 0.1-0.1)$, in order to evaluate the effect of their inclusion in the film matrix on their activity. Instead of the protein dilutions, films with the same area were placed on the inoculated TSA-NaCl petri dishes. The film free drying surface (where the highest density of protein was found) was always put in contact with the agar medium. Inoculated petri dishes without film were used as inoculum control, while inoculated dishes coated with the starch film without proteins (sample 0-0) were used as film control. All the tests were also run in triplicate. 
The effectiveness of the antimicrobial ability of the films in a real food system was tested in

\subsubsection{Antioxidant tests}

\subsubsection{ABTS radical scavenging assay}

The antioxidant capacity of LF, LZ, and their 1:1 wt. ratio blend was determined through a spectrophotometric method, as described by $\operatorname{Re}$ et al. (1999). The objective of this method is to compare the antioxidant activity of the analyzed substance with that of an antioxidant standard, trolox (6-hydroxy-2,5,7,8-tetramethylchroman-2-carboxylic acid), a vitamin $E$ analogue.

ABTS (2,2'-azino-bis[3-ethylbenzothiazoline-6-sulphonic acid]) was dissolved in water to a concentration of $7 \mathrm{mM}$, and allowed to react with a $2.45 \mathrm{mM}$ potassium persulfate solution (final concentrations) for $16 \mathrm{~h}$ in the dark. ABTS radical cation (ABTS ${ }^{+}$), a blue chromophore, was produced during that period. The ABTS ${ }^{+}$solution was diluted with ethanol until an initial absorbance of 0.70 $( \pm 0.02)$ at $734 \mathrm{~nm}\left(\mathrm{~A}_{0}\right) .10 \mu \mathrm{l}$ of the test solution was added to $990 \mu \mathrm{L}$ of this solution, and the percentage of absorbance reduction at 6 minutes was registered. All absorbance measurements were taken with a Beckman Coulter DU 730 spectrophotometer, using ethanol as blank. In order to obtain the test solutions, both LF and LZ, as well as their blend, were completely dissolved at $5 \%$ in bidistilled water while stirring at $250 \mathrm{rpm}$ for $16 \mathrm{~h}$. All tests were performed in triplicate.

A calibration curve (\% absorbance reduction vs. concentration of Trolox) was obtained with different dilutions $(0 \mathrm{mg} / \mathrm{l}$ to $50 \mathrm{mg} / \mathrm{l})$ of trolox as standard antioxidant agent. The Trolox equivalent antioxidant capacity (TEAC) of the proteins was defined as the concentration (g protein/L) producing the same perceptual absorbance reduction as $1 \mathrm{mM}$ Trolox. 
The antioxidant ability of the films containing $0.2 \mathrm{~g}$ protein $/ \mathrm{g}$ starch (samples $0.2-0 ; 0-0.2 ; 0.1-0.1$ ) was tested on a real food system, pure fresh fat (lard), which was purchased in a local market and kept in refrigeration until the experiment was started (no more than $24 \mathrm{~h}$ ). Inert glass cups (36.5 mm diameter and $6.6 \mathrm{~mm}$ depth) were totally filled with fat and compressed to ensure the total absence of air bubbles. At this point, each cup surface was completely covered with a film disk. The film free drying surface (where the highest density of protein was found) was always put in contact with the lard. Non-covered cups and cups covered with film without protein (0-0) were used as controls. All the samples were stored at $40^{\circ} \mathrm{C}$ and $53 \%$ $\mathrm{RH}$ for 190 days. The extent of fat oxidation was evaluated throughout the storage by obtaining the peroxide value (PV). An automatic titrator was employed to perform the measurements (Titrando, Metrohm Ion Analysis, Switzerland). With this aim, between $1 \mathrm{~g}$ and $2 \mathrm{~g}$ of lard was dissolved in $10 \mathrm{~mL}$ of solvent (glacial acetic acid and 1-decanol containing 10-15 mg iodine, in a 3:2 mass ratio) and blended with $200 \mu \mathrm{L}$ of an oversaturated $\mathrm{KI}$ solution. The mixture was thoroughly mixed and kept in the dark for $1 \mathrm{~min}$. Then, $50 \mathrm{~mL}$ of distilled water was added and the solution was titrated with $0.01 \mathrm{M}$ or $0.001 \mathrm{M} \mathrm{Na}_{2} \mathrm{~S}_{2} \mathrm{O}_{3}$, depending on the PV predicted. Prior to the test, a blank value of solvent was obtained following the procedure mentioned above, without the addition of lard. PV was expressed as mequivalents of oxygen per kilogram of pork fat. All the analyses were performed in triplicate.

\subsection{Statistical analysis}

The statistical analysis of the data was performed through analysis of variance (ANOVA) using Statgraphics Centurion XVI. II. Fisher's least significant difference (LSD) procedure was used.

\section{Results and discussion}

\subsection{Microstructural characterization}

Figure 1 shows the SEM images of PS films (cross section and film surface) while Figures 2 and 3 show, respectively, SEM images of the cross section of the blend films and their surface, after 1 week of storage. The films with no protein (Figure 1) exhibited a homogeneous, compact structure without pores. Protein addition gave rise to more heterogeneous structures, as a result of the partial incompatibility of both proteins and starch. On blend film surfaces (Figure 3), globular formations can be observed which can be attributed to protein separation from the starch matrix, in agreement with a lack of complete miscibility of the polymers. The limited miscibility favoured protein creaming during the film drying, due to their lower density, which implied a heterogeneous distribution of protein through the film matrix. 


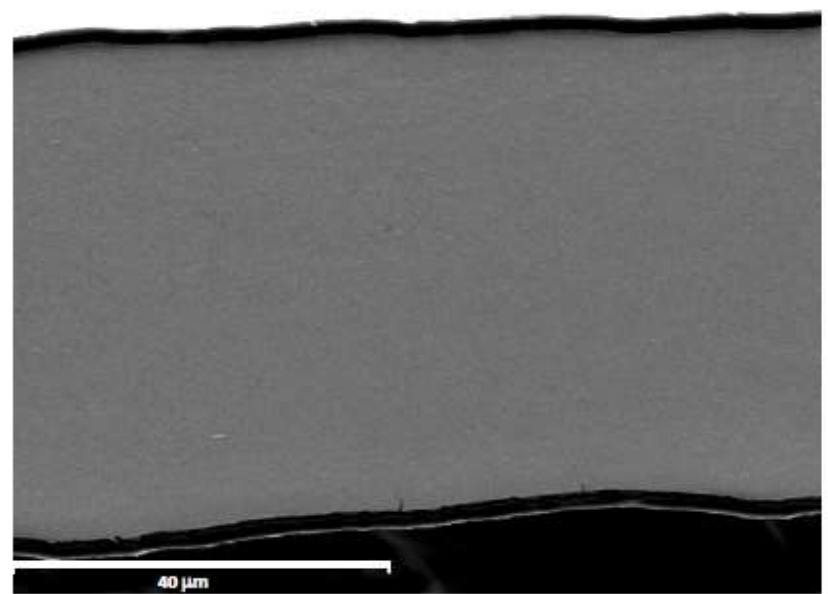

Cross section

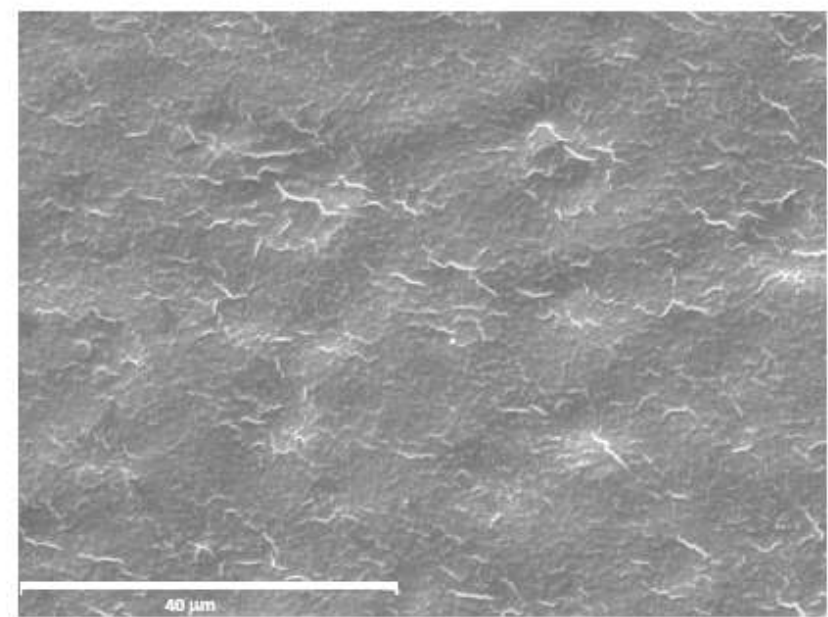

Surface

FIGURE 1. SEM images of the cross section and surface of dried net starch films (0:0 sample).

349

Likewise, the fact that a protein fraction remained dispersed in the PS matrix produced discontinuities, which generated micro-fractures in the film structure. This fragility was mainly noticeable in films with LF, particularly in the films with the highest LF proportion (sample 0.2-0), which suggests that PS is more compatible with $L Z$ than LF. With the same protein ratio, films containing $L Z$ or LZ-LF blends appeared more homogenous without discontinuities in the matrix. Differences in the proteins' compatibilities could be due to differences in their molecular weight, namely $80 \mathrm{kDa}$ for LF (Barbiroli et al., 2012) and 14.4 kDa for LZ (Corradini et al., 2013) as well as their aminoacid sequence (primary structure) and the secondary and the tertiary structures, which can play a key role in the chemical interactions with the starch matrix. These differing molecular structures would, in turn, affect the availability of functional groups able to establish favourable interactions with the starch chains. 

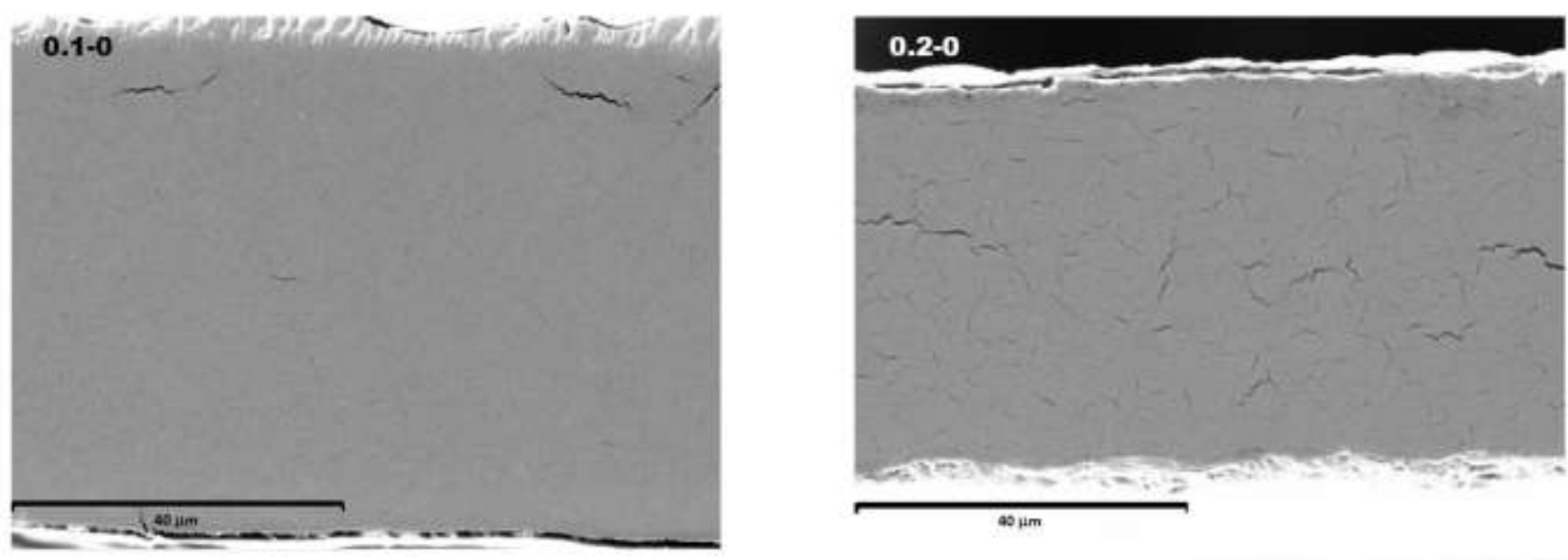

\section{$0-0.1$}
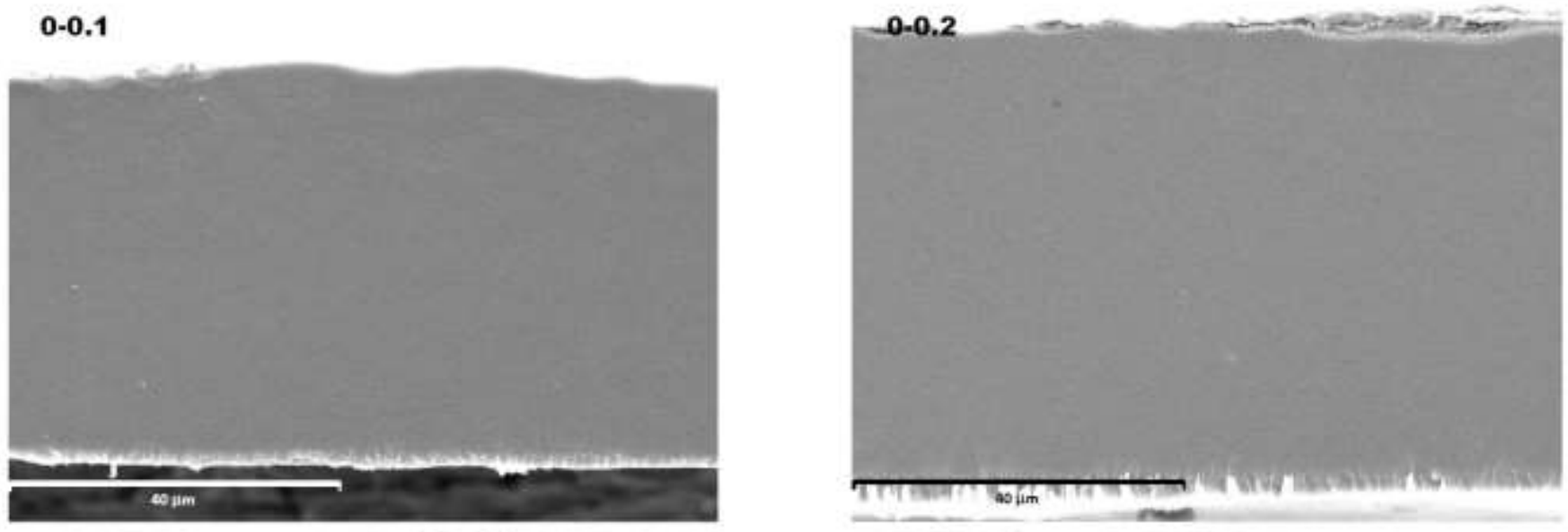

\section{$0.05-0.05$}
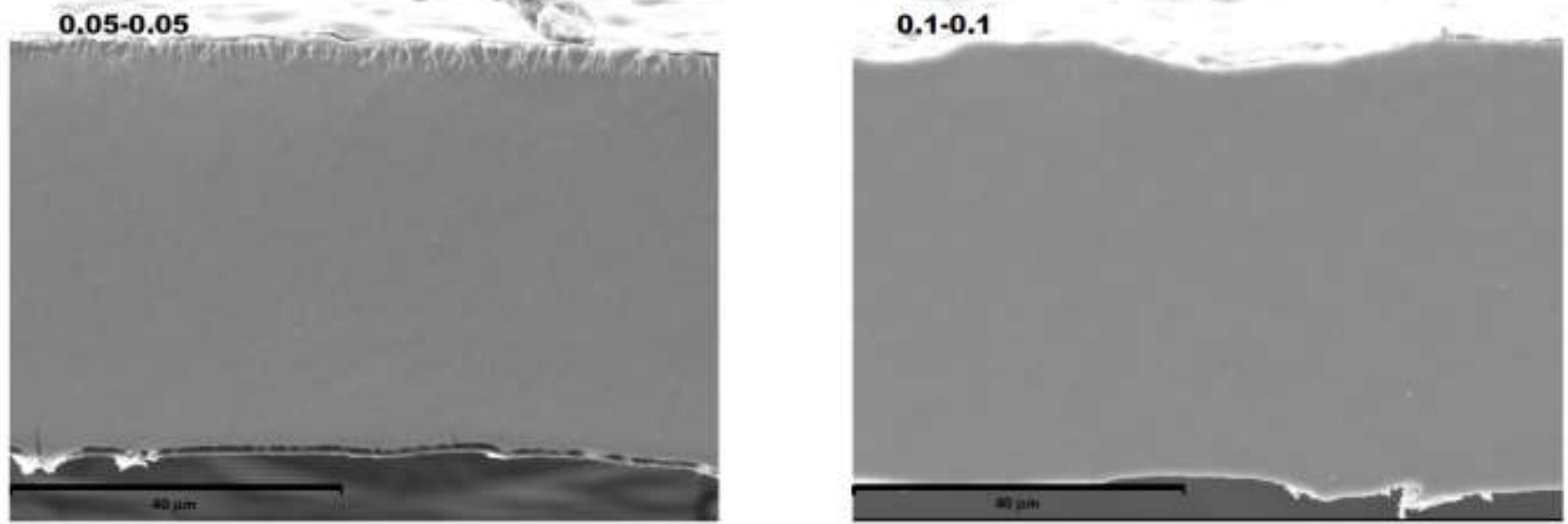

FIGURE 2. SEM images of the cross section of the dried films. Sample codes refer to the mass ratio of LF (first digit) and LZ (second digit) with respect to PS. 

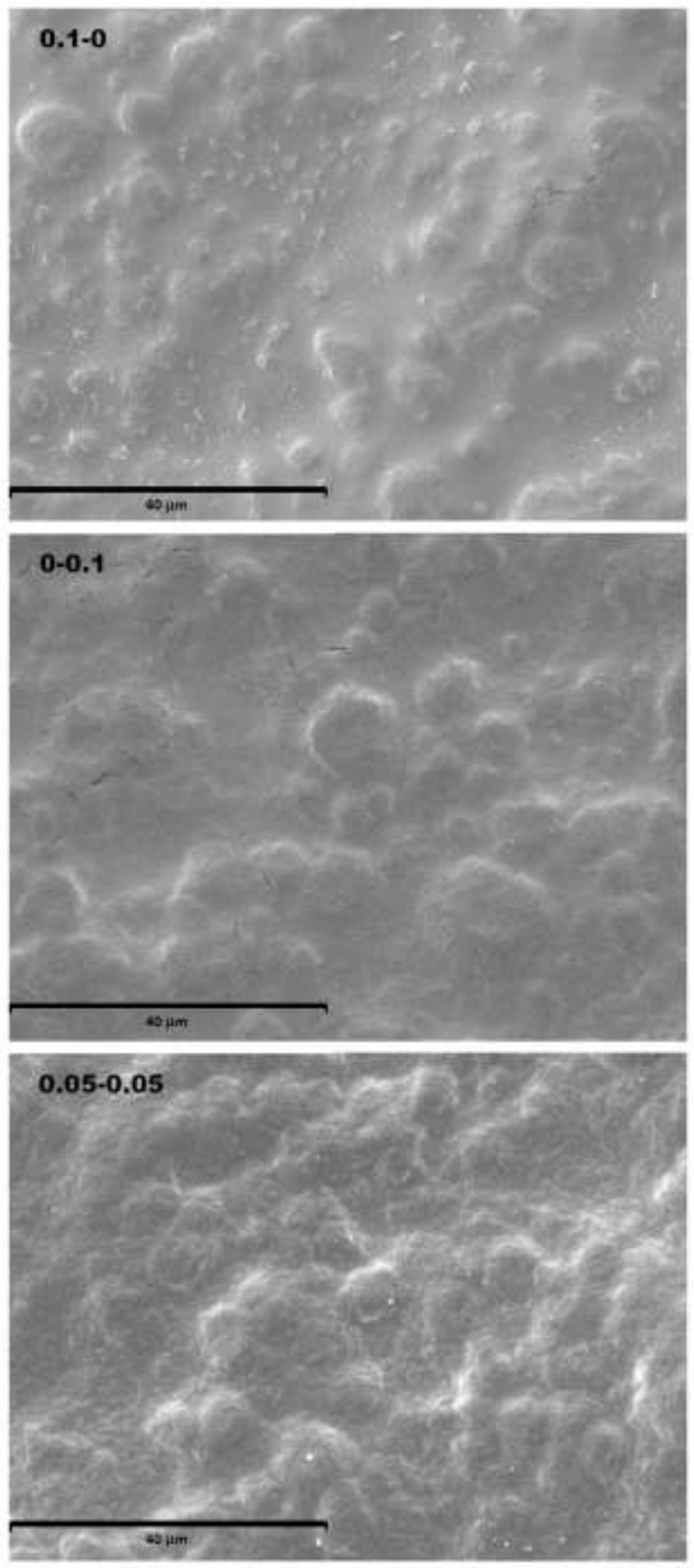

FIGURE 3. SEM images of the surface of the dried films. Sample codes refer to the mass ratio of LF (first digit) and LZ (second digit) with respect to PS.
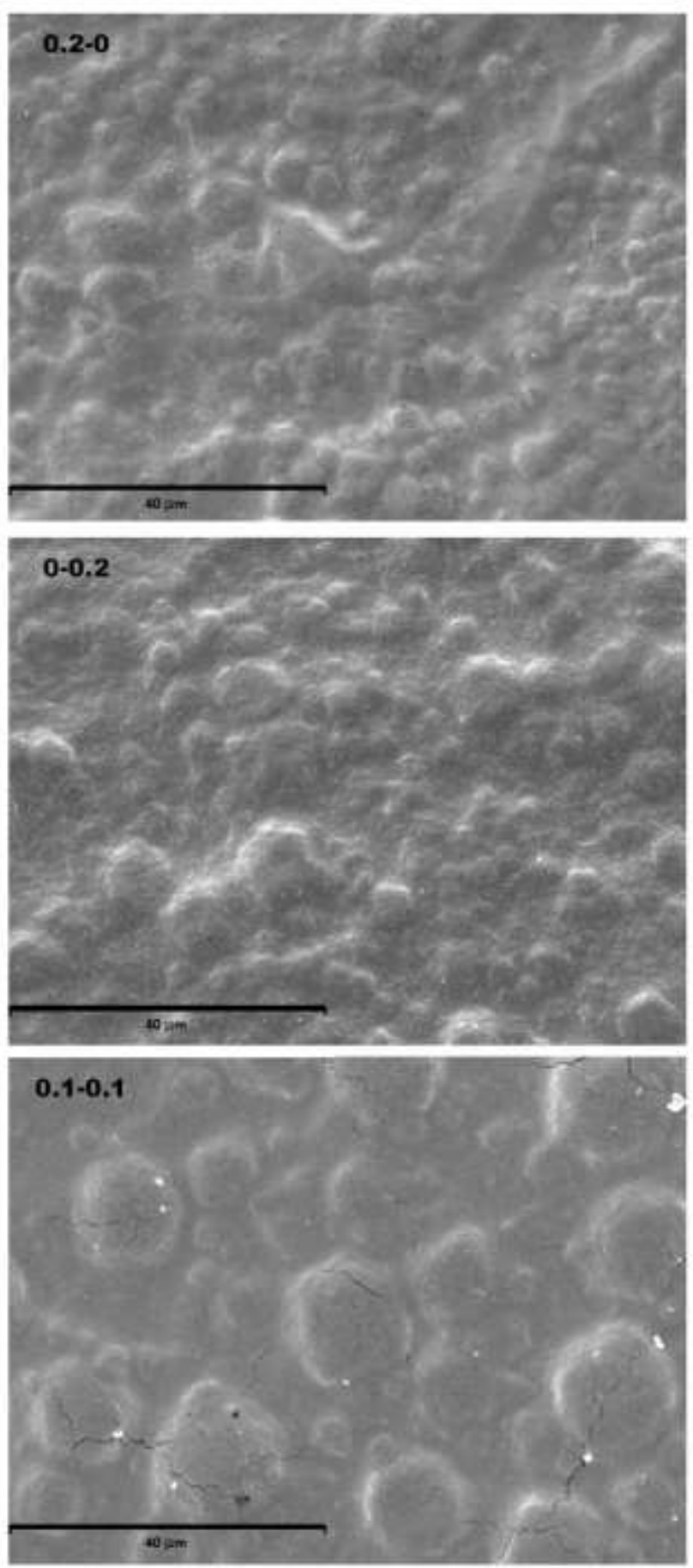

\subsection{Thermal characterization}

Figure 4a shows the thermal degradation curves, determined by TGA, of the different films and pure proteins, where the influence of proteins (type and content) in the starch-based films' thermal behavior can be appreciated. A first weight loss step with a peak temperature near $100^{\circ} \mathrm{C}$ was observed in all cases, due to the initial dehydration of the films. Table 1 shows the values of the initial 
degradation temperature $\left(T_{0}\right)$, maximum degradation rate temperature $\left(T_{\max }\right.$, in Figure $\left.4 \mathrm{~b}\right)$ and the percentage mass loss at the end of the TGA test $\left(600^{\circ} \mathrm{C}\right)$ for both the pure proteins and films.

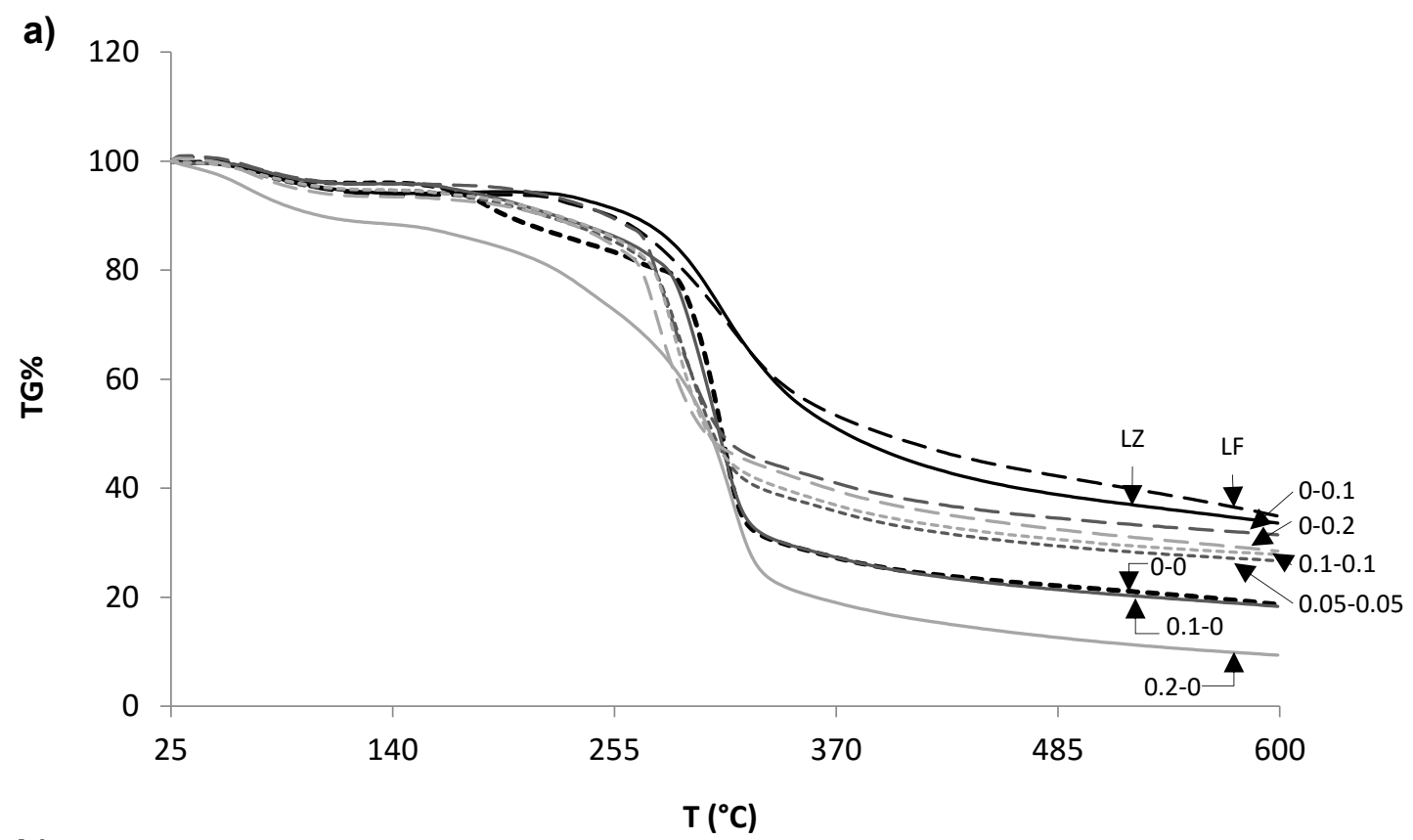

b)

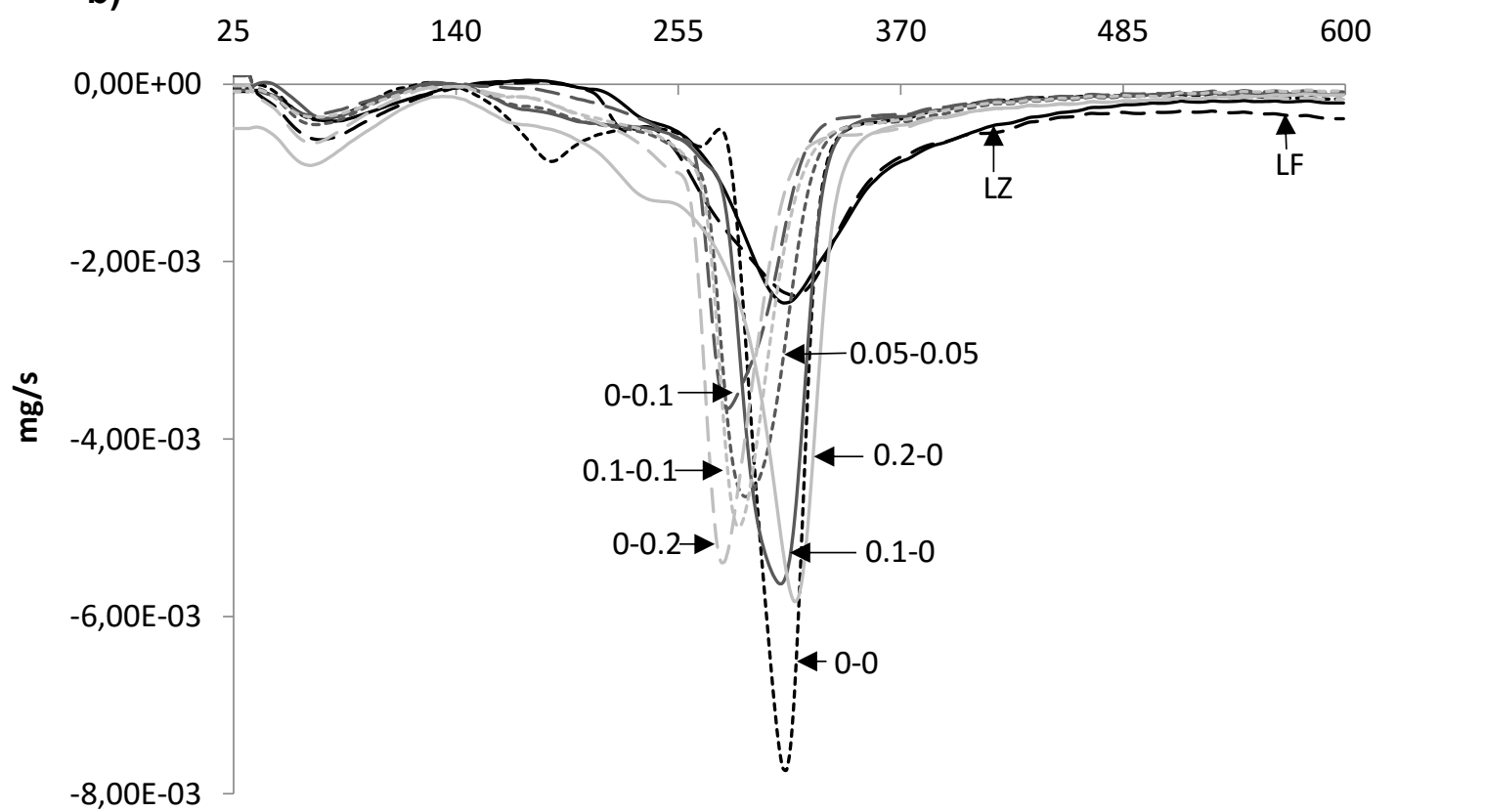

FIGURE 4. a) Thermogravimetric curves for the film samples and pure proteins ( $L Z$ and LF) . b) First derivative from TGA curves for the film samples and pure proteins (LF and LZ). Sample codes refer to the mass ratio of LF (first digit) and LZ (second digit) with respect to PS.

The $T_{0}$ and $T_{\max }$ values of the starch films (sample $0-0$ ) were $282^{\circ} \mathrm{C}$ and $310^{\circ} \mathrm{C}$, respectively, similar to previous reported values for potato, wheat and maize starch films (He et al., 2012; Soares et al., 2005). These values were significantly higher $(p<0.05)$ than that of the pure proteins (Table 1$)$, which showed a similar degradation behaviour, although LF degraded slightly faster according to its 
lower molecular weight. Protein incorporation into starch films provoked significant changes in the degradation pattern of the films, depending on the protein type and ratio, always decreasing the $T_{0}$ and $T_{\max }$ values, but in some cases reducing the percentage mass loss.

It is remarkable that, whereas films with 0.1 of LF show degradation curve which practically overlaps with that of starch films, samples with $0.2 \mathrm{LF}$ showed the highest and fastest thermal degradation. Nevertheless, LZ or LZ-LF blends slightly accelerated the thermal degradation of the starch films, but reduced the total mass loss with respect to pure starch or starch-LF films. In this sense, it is remarkable that residual mass loss was greater for pure proteins than for starch films and that starch films containing LZ (pure or blended with LF) showed an intermediate residual mass between net starch and proteins, in contrast with films containing only LF which exhibit higher mass degradation. This suggests that degradation compounds are different depending on the presence of protein and its type, thus also pointing out to the different starch-protein interactions in each case, as deduced from the microstructural observations. Hydrogen bonds between hydroxyl groups of starch and amino group of the protein chains can occur to different extent depending on the protein conformation in the blend. In fact, helical conformation of amylose could entrap different segments of the proteins, as occurs with other organic compounds, in a selective way.

TABLE 1. Thermal properties of the films obtained by TGA $\left(T_{0}, T_{\max }, \%\right.$ Mass loss at $\left.600^{\circ} \mathrm{C}\right)$ and DSC (Tg).

\begin{tabular}{lcccc}
\hline \multicolumn{1}{c}{ Film sample } & $\mathrm{T}_{\mathbf{0}}\left({ }^{\circ} \mathbf{C}\right)$ & $\mathbf{T}_{\max }\left({ }^{\circ} \mathbf{C}\right)$ & \%Mass loss & $\mathbf{T}_{\mathbf{g}}\left({ }^{\circ} \mathbf{C}\right)$ \\
\hline $\mathbf{0 - 0}$ & $282.1 \pm 0,4^{\mathrm{e}}$ & $310.3 \pm 0.2^{\mathrm{d}}$ & $80.4 \pm 1.3^{\mathrm{e}}$ & $125.9 \pm 0.2^{\mathrm{a}}$ \\
$\mathbf{0 . 1 - 0}$ & $279.1 \pm 0.4^{\mathrm{e}}$ & $308.1 \pm 0.4^{\mathrm{d}}$ & $77 \pm 7^{\mathrm{de}}$ & $129.62 \pm 1.07^{\mathrm{b}}$ \\
$\mathbf{0 - 0 . 1}$ & $265.1 \pm 0.5^{\mathrm{c}}$ & $281.1 \pm 0.7^{\mathrm{a}}$ & $67.4 \pm 1.7^{\mathrm{abc}}$ & $153.2 \pm 0.9^{\mathrm{c}}$ \\
$\mathbf{0 . 0 5 - 0 . 0 5}$ & $270.0 \pm 0.3^{\mathrm{d}}$ & $290.8 \pm 0.2^{\mathrm{c}}$ & $73.1 \pm 0.2^{\mathrm{cd}}$ & $138.6 \pm 0.7^{\mathrm{c}}$ \\
$\mathbf{0 . 2 - 0}$ & $283 \pm 5^{\mathrm{e}}$ & $314 \pm 2^{\mathrm{e}}$ & $88 \pm 4^{\mathrm{f}}$ & $138.9 \pm 1.1^{\mathrm{c}}$ \\
$\mathbf{0 - 0 . 2}$ & $263.0 \pm 0.9^{\mathrm{bc}}$ & $278.3 \pm 0.5^{\mathrm{a}}$ & $71.1 \pm 0.6^{\mathrm{abcd}}$ & $161.8 \pm 0.2^{\mathrm{d}}$ \\
$\mathbf{0 . 1 - 0 . 1}$ & $269.0 \pm 0.3^{\mathrm{d}}$ & $286.1 \pm 0.4^{\mathrm{b}}$ & $72.3 \pm 0.2^{\mathrm{bcd}}$ & $154.6 \pm 1.5^{\mathrm{c}}$ \\
LF & $248.4 \pm 0.3^{\mathrm{a}}$ & $317 \pm 4^{\mathrm{e}}$ & $65.25 \pm 0.19^{\mathrm{a}}$ & - \\
LZ & $259.4 \pm 0.8^{\mathrm{b}}$ & $309.2 \pm 0.5^{\mathrm{d}}$ & $66.36 \pm 0.09^{\mathrm{ab}}$ & - \\
\hline
\end{tabular}
Sample codes refer to the mass ratio of LF (first digit) and LZ (second digit) with respect to PS.

Table 1 also shows the values of the glass transition temperature $\left(T_{g}\right)$ of the films. The $T_{g}$ values of potato starch films without protein were similar to previously reported values for potato starch (Farahnaky et al., 2009). As proteins were incorporated into the film, a significant increase $(p<0.05)$ of $T_{g}$ was found. This increase was promoted when the protein ratio increased and was more marked for films with LZ. This suggests that molecular interactions between the starch and the protein chains occurred in the films to a different extent depending on the kind of protein and the ratio. Likewise, the increase indicates that the amorphous starch region behaves with a higher mean molecular weight, which could be explained through the establishment of protein-amylose or amylopectin bonds forming starch-protein complexes. As commented on in section 3.1, LZ seemed to interact with PS to a greater extent than LF, thus leading to the highest complexation degree and, thereby, a greater $T_{g}$ increase. 
At both protein:starch ratios, the films with the two proteins showed $T_{g}$ values between those of films with only one protein. This behaviour points to a partial miscibility of both proteins with starch chains, through complex formation with a higher mean molecular weight than starch chains. This was more notable for LZ, in agreement with a higher protein compatibility with starch.

\subsection{Physical characterization}

\subsubsection{THICKNESS, WATER CONTENT AND MECHANICAL PROPERTIES}

The thickness of the obtained films ranged between 60 and $80 \mu \mathrm{m}$ (results not shown). The protein addition led to thicker films, coherently with the protein proportion with respect to PS. This indicates that the packing of starch chains was partially limited by the presence of protein in the films probably due to the induced changes in the chain interactions.

Figure 5 shows stress-strain curves for the films stored for 1 week at 33 and $53 \%$ relative humidity. Protein incorporation greatly reduced the films' stretchability, even when conditioned at $53 \%$ $\mathrm{RH}$, when net starch films showed a notable extensibility due to the increase in water content and its plasticization effect. This was not observed for protein-containing films, which must be attributed to the discontinuities introduced in the starch matrix which increased its brittleness and to the anti-plasticizing role of the proteins ( $\mathrm{Tg}$ increase) in the starch blend.

33\% RH 1 week storage

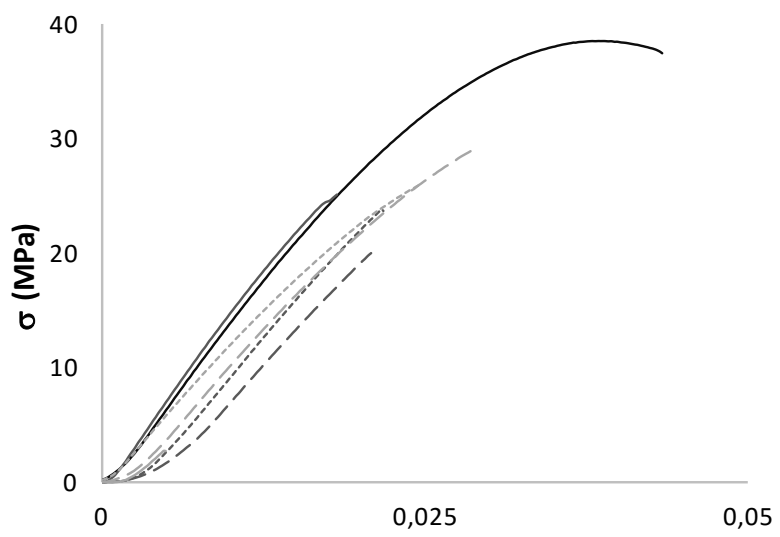

$\boldsymbol{\varepsilon}_{\boldsymbol{H}}$

\section{$53 \%$ RH 1 week storage}

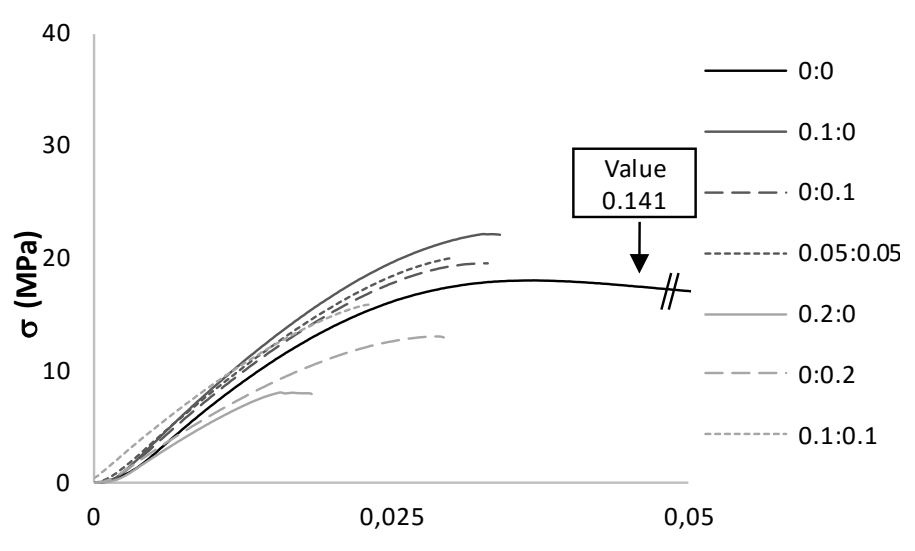

$\boldsymbol{\varepsilon}_{\mathbf{H}}$

FIGURE 5. Stress - strain curves of the films conditioned for 1 week at $33 \%$ and $53 \% \mathrm{RH}$. Sample code refers to mass ratio of LF (first digit) and LZ (second digit) with respect to PS.

Figure 6 shows the values of the mechanical parameters and moisture content of all the studied films conditioned for 1 and 5 weeks at $30 \%$ and $45 \% \mathrm{RH}$. The elasticity modulus (EM (MPa)), is related with the stiffness of the film; the tensile strength (TS (MPa)) corresponds to the resistance to fracture and the deformation percentage at break (\%E) describes the stretchability of the films. Films showed 4 levels of moisture content depending on the time and $\mathrm{RH}$ of conditioning. These levels ranged 

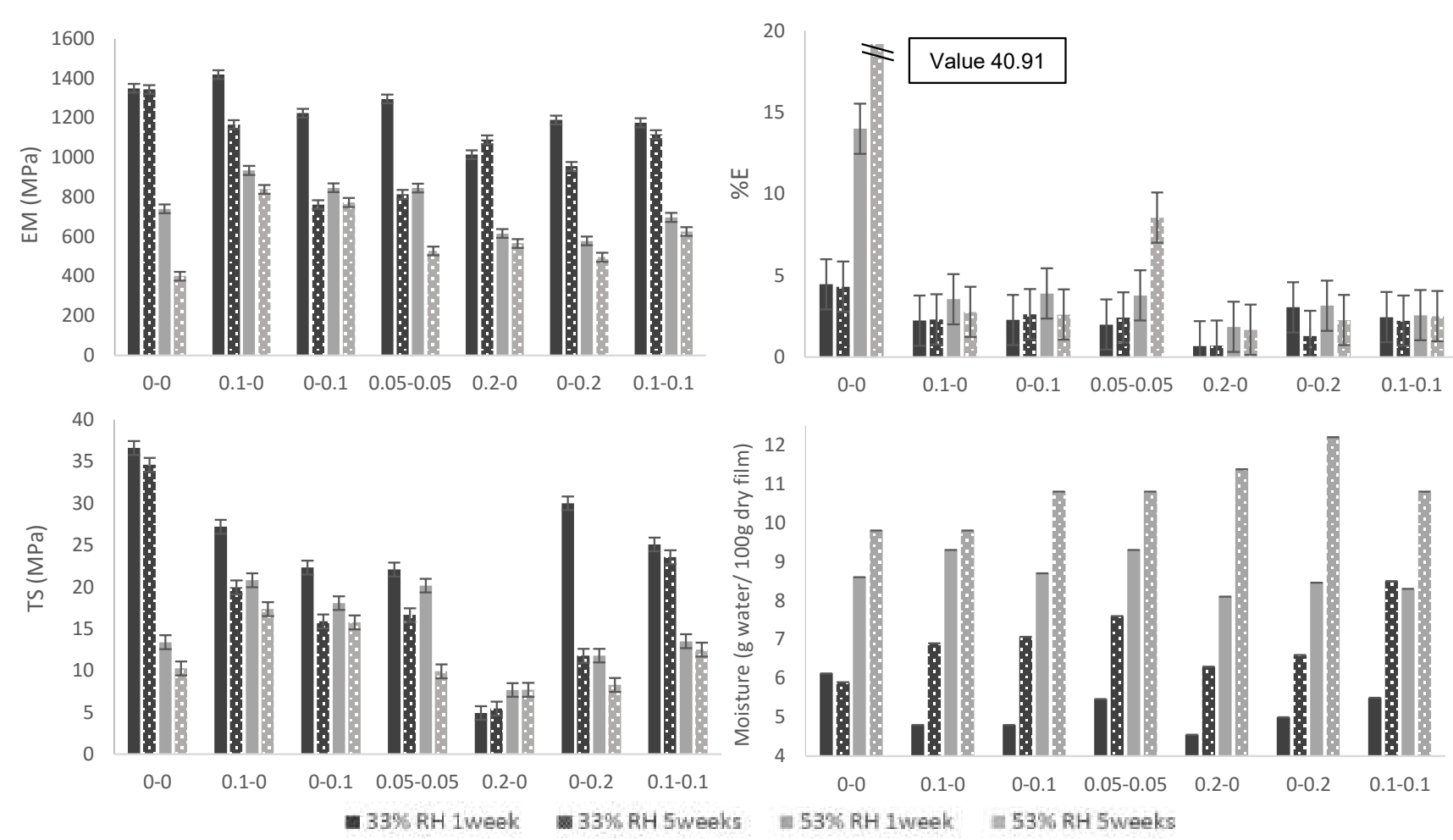

FIGURE 6. Values of the mechanical parameters (elastic modulus -EM (MPa)- tensile strength -TS (MPa)- and deformation - \%E- at break) and moisture content of the films conditioned for 1 and 5 weeks at $33 \%$ and $53 \% \mathrm{RH}$ and $25{ }^{\circ} \mathrm{C}$. Sample codes refer to the mass ratio of LF (first digit) and LZ (second digit) with respect to PS. Mean values and 95\% LSD intervals.

Water uptake provoked a significant decrease in EM and TS of net starch films while film stretchability was enhanced. This expected behaviour, associated with the water plasticization effect, has previously been described for corn starch films containing $25 \%$ glycerol, establishing the critical water content for an effective water plasticization at about $9 \%$ (Jiménez et al. 2013). In films containing proteins, water plasticization also occurred, thus decreasing EM and TS when moisture content rose, but did not suppose a notable increase in the elongation at break, which showed very low values for all moisture contents in every film. Only the film sample 0.1-0.1 with the highest moisture content showed a significantly higher elongation at break, as compared with the other films with proteins. Likewise, films with 0.2 LF were especially brittle, showing the lowest values of TS and $\% \mathrm{E}$, regardless of their moisture content. This behaviour suggests that, although starch matrix was 
plasticised in all cases, the overall weakening of the starch network cohesion forces due to the presence of protein chains, and the development of specific molecular interactions with the starch

\subsubsection{WATER VAPOUR AND OXYGEN PERMEABILITIES}

The water vapour permeability (WVP) of the films after 1 and 5 weeks of storage is reported in Table 2. This parameter is closely linked to the films' ability to reduce the water vapour diffusivity when applied to food products, and accordingly it should be as low as possible (Ma et al., 2008). The WVP of films with net starch (sample 0-0) was in the order of those previously reported by Han et al., 2006, Ma et al., 2008, Jiménez et al., 2012 and Cano et al. 2014 for different starch films. WVP was slightly reduced when proteins were added to the films, according to their ratio. This improvement in the water vapour barrier could be due to two combined effects: the specific interactions between the starch and the proteins, which implied a greater $\mathrm{Tg}$ of the amorphous matrix and the formation of a surface protein layer, as observed by SEM, on the top of the film (Figure 3). WVP values of some protein films are lower than those of starch films (Monedero et al., 2010), which, in turn, can contribute to modify barrier properties of blend films. No significant differences $(p>0.05)$ were observed in WVP values due to the storage time, despite the abovementioned increase in the moisture content of the films. So, the small changes in water content in the films did not notably affect their water vapour barrier properties.

The oxygen permeability (OP) of the films is also reported in Table 2. OP values of net starch film were similar to those previously reported by Cano et al., (2014) for potato starch films, after both 1 and 5 storage weeks. They also observed a decrease in OP after storage time, which was attributed to the structural changes in the starch matrix, such as the progressive chain aggregations, that enhance the oxygen barrier properties, by limiting the mass transport of gas molecules. The protein addition led to a decrease in OP values in the films, with no significant changes due to the storage time. This behaviour can be explained in terms of the formation of starch-protein bonds, as commented on in section 3.1, which increased the effective size of the polymer chains, thus being more effective at limiting mass transfer processes. Likewise, the absence of changes in OP of the protein-containing films throughout time indicates that structural changes in starch matrix could be limited by protein interactions. No notable differences in oxygen barrier properties due to the kind or ratio of proteins were observed. 
TABLE 2. Values of the water vapor permeability (WVP) and oxygen permeability (OP) for films conditioned at $53 \% \mathrm{RH}$ and $25^{\circ} \mathrm{C}$ for 1 and 5 weeks.

507

508

509

510

511

512

513

514

\begin{tabular}{|c|c|c|c|c|c|}
\hline \multicolumn{2}{|c|}{ Samples } & \multicolumn{2}{|c|}{ WVP $\left(\mathrm{g} \cdot \mathrm{mm} / \mathrm{kPa} \cdot \mathrm{h} \cdot \mathrm{m}^{2}\right)$} & \multicolumn{2}{|c|}{$\begin{array}{c}\text { OP } \\
\left(10^{-14} \mathrm{~cm}^{3} / \mathrm{m} \mathrm{s} \mathrm{Pa}\right)\end{array}$} \\
\hline & & $1 \mathrm{w}$ & $5 w$ & $1 \mathrm{w}$ & $5 w$ \\
\hline \multirow{7}{*}{ Films } & $0-0$ & $6.70 .3^{c, 1}$ & $7.5 \pm 0.8^{\mathrm{d}, 1}$ & $15.7 \pm 1.0^{c, 2}$ & $8.64 \pm 0.09 \underline{a}, 1$ \\
\hline & $0.1-0$ & $6.4 \pm 0.16^{\mathrm{bc}, 1}$ & $6.7 \pm 0.4^{\mathrm{cd}, 1}$ & $13 \pm 3^{a b c, 1}$ & $10 \pm 3 \underline{a}, 1$ \\
\hline & $0-0.1$ & $6.1 \pm 0.3^{b, 1}$ & $5.8 \pm 0.3^{\mathrm{abc}, 1}$ & $14.0 \pm 0.3^{b c, 1}$ & $11 \pm 1 \mathrm{a}, 1$ \\
\hline & 0.05-0.05 & $6.4 \pm 0.4^{b c, 1}$ & $5.9 \pm 0.3^{a b c, 1}$ & $11.83 \pm 0.17^{a b, 1}$ & $10 \pm 2 \stackrel{a}{a}, 1$ \\
\hline & $0.2-0$ & $5.66 \pm 0.14^{a, 1}$ & $6.4 \pm 1.1^{b c, 1}$ & $10 \pm 1 \underline{a}, 1$ & $9.50 \pm 0.16 \stackrel{a}{a}, 1$ \\
\hline & $0-0.2$ & $5.62 \pm 0.11^{a, 1}$ & $5.7 \pm 0.3^{\mathrm{ab}, 1}$ & $12 \pm 2^{\mathrm{ab}, 1}$ & $9.787 \pm 0.014 \stackrel{a}{a}, 1$ \\
\hline & $0.1-0.1$ & $6.49 \pm 0.17^{\mathrm{c}, 2}$ & $5.6 \pm 0.3^{a, 1}$ & $10 \pm 1^{a}, 1$ & $9.058 \pm 0.119 \underline{a}, 1$ \\
\hline
\end{tabular}

Different letters $(a, b, c)$ in the same column indicate significant differences among the different formulations for the same storage time $(p<0.05)$.

Different numbers $(1,2)$ in the same row indicate significant differences between both storage times for the same formulation $(p<0.05)$.

Sample codes refer to the mass ratio of LF (first digit) and LZ (second digit) with respect to PS.

\subsubsection{OPTICAL PROPERTIES: TRANSPARENCY, COLOUR AND GLOSS}

Table 3 shows the corresponding colour parameters (lightness, chroma, and hue), the gloss values at $60^{\circ}$, and the internal transmittance $\left(T_{i}\right)$ at $430 \mathrm{~nm}$, as an indicator of their transparency, for the different films conditioned for both 1 and 5 weeks. Protein incorporation provoked a statistically significant reduction $(p<0.05)$ in the film transparency $\left(T_{i}\right.$ values) at $430 \mathrm{~nm}$. The most relevant reduction was found for films with LF, due to the selective light absorption of LF components. This agrees with the greater structural heterogeneity of films with protein, which introduced changes in the refractive index through the films, thus promoting light scattering. The higher the protein ratio, the greater the light dispersion and the transparency reduction. Selective light absorption of LF led to film coloration, as commented on below.

Net starch films were practically colourless, as revealed by the very low Chroma values and high lightness. Some lightness reduction was observed in the films after both 1 and 5 storage weeks, with no relevant effect of the protein ratio. LF incorporation had an important effect on the Chroma and hue values, causing a significant increase in both $(p<0.05)$, in agreement with its selective light absorption at low wavelength $(430 \mathrm{~nm})$. Coherently, those films with protein blend also showed Chroma increase and greater redness.

Gloss of the starch films was reduced by protein incorporation by about half, which can be attributed to the increase in their surface roughness associated with the protein migration to the film surface, observed by SEM. While no changes in gloss were observed for films containing proteins at different storage times, net starch films reduced their gloss during storage, such as has previously been observed by other authors (Jiménez et al. 2012; Cano et al. 2014). This change has been 

mobility.

TABLE 3. Colour parameters of the films $\left(L^{*}, C_{a b}{ }^{*}, h^{*}\right)$, gloss at $60^{\circ}$ and Ti at $430 \mathrm{~nm}$ after 1 and 5 storage weeks at $25^{\circ} \mathrm{C}$ and $54 \% \mathrm{RH}$.

\begin{tabular}{|c|c|c|c|c|c|c|c|c|c|c|}
\hline \multirow{2}{*}{$\begin{array}{c}\text { Film } \\
\text { samples }\end{array}$} & \multicolumn{2}{|c|}{$\mathrm{L}^{*}$} & \multicolumn{2}{|c|}{$h_{a b} *$} & \multicolumn{2}{|c|}{$\mathrm{C}_{\mathrm{ab}} *$} & \multicolumn{2}{|c|}{$T_{i}(430 \mathrm{~nm})$} & \multicolumn{2}{|c|}{ Gloss $\left(60^{\circ}\right)$} \\
\hline & $1 \mathrm{w}$ & $5 w$ & $1 \mathrm{w}$ & $5 w$ & $1 w$ & $5 w$ & $1 w$ & $5 w$ & $1 \mathrm{w}$ & $5 w$ \\
\hline \multirow{2}{*}{$0-0$} & 84.6 & 84.4 & 286 & 302 & 1.2 & 0.99 & 0.858 & 0.850 & 22.7 & 15 \\
\hline & $\pm 0.4^{e, 1}$ & $\pm 0.7^{e, 1}$ & $\pm 6^{b, 1}$ & $\pm 3^{d, 2}$ & $\pm 0.5^{a, 1}$ & $\pm 0.13^{a, 1}$ & $\pm 0.004^{e, 1}$ & $\pm 0.007^{c, 1}$ & $\pm 1.9^{\mathrm{d}, 2}$ & $\pm 3^{d, 1}$ \\
\hline \multirow{2}{*}{$0.1-0$} & 77.35 & 79.0 & 63.8 & 63.41 & 8.3 & 7.58 & 0.826 & 0.832 & 8.3 & 10.3 \\
\hline & $\pm 0.009^{a, 1}$ & $\pm 0.2^{b, 2}$ & $\pm 0.5^{a, 1}$ & $\pm 1.08^{b, 1}$ & $\pm 0.6^{d, 1}$ & $\pm 0.05^{e, 1}$ & $\pm 0.002^{b, 1}$ & $\pm 0.007^{b, 1}$ & $\pm 0.7^{a, 1}$ & $\pm 0.9^{c, 2}$ \\
\hline \multirow{2}{*}{$0-0.1$} & 83.1 & 82.01 & 308 & 308 & 1.4 & 1.2 & 0.850 & 0.851 & 8.3 & 8.8 \\
\hline & $\pm 0.6^{\mathrm{d}, 1}$ & $\pm 1.15^{\mathrm{d}, 1}$ & $\pm 17^{\mathrm{c}, 1}$ & $\pm 10^{\mathrm{d}, 1}$ & $\pm 0.5^{a, 1}$ & $\pm 0.3^{a, 1}$ & $\pm 0.005^{\mathrm{d}, 1}$ & $\pm 0.002^{c, 1}$ & $\pm 0.7^{a, 1}$ & $\pm 0.6^{\mathrm{ab}, 1}$ \\
\hline \multirow{2}{*}{$0.05-0.05$} & 80.8 & 79.0 & 67.13 & 63.92 & 5.2 & 4.6 & 0.840 & 0.835 & 8.5 & 8.4 \\
\hline & $\pm 0.9^{\mathrm{c}, 2}$ & $\pm 0.2^{b, 1}$ & $\pm 1.08^{\mathrm{a}, 2}$ & $\pm 1.12^{\mathrm{b}, 1}$ & $\pm 0.8^{b, 1}$ & $\pm 0.2^{c, 1}$ & $\pm 0.002^{\mathrm{c}, 2}$ & $\pm 0.005^{b, 1}$ & $\pm 0.8^{\mathrm{a}, 1}$ & $\pm 0.8^{a, 1}$ \\
\hline \multirow{2}{*}{$0.2-0$} & 76.4 & 75.8 & 59.0 & 57.36 & 11.3 & 10.4 & 0.811 & 0.813 & 8.23 & 8.52 \\
\hline & $\pm 0.3^{a, 2}$ & $\pm 0.5^{a, 1}$ & $\pm 0.6^{a, 2}$ & $\pm 0.18^{a, 1}$ & $\pm 1.2^{\mathrm{e}, 1}$ & $\pm 0.3^{f, 1}$ & $\pm 0.004^{a, 1}$ & $\pm 0.006^{a, 1}$ & $\pm 0.17^{a, 1}$ & $\pm 0.16^{a b, 2}$ \\
\hline \multirow{2}{*}{$0-0.2$} & 84.2 & 84.82 & 300 & 292 & 1.6 & 2.0 & 0.851 & 0.853 & 10.1 & 9.6 \\
\hline & $\pm 0.9^{e, 1}$ & $\pm 1.13^{\mathrm{e}, 1}$ & $\pm 13^{\mathrm{c}, 1}$ & $\pm 5^{c, 1}$ & $\pm 0.7^{a, 1}$ & $\pm 0.5^{b, 1}$ & $\pm 0.003^{d, 1}$ & $\pm 0.003^{c, 1}$ & $\pm 0.6^{c, 2}$ & $\pm 0.6^{\mathrm{bc}, 1}$ \\
\hline \multirow{2}{*}{$0.1-0.1$} & 79.3 & 80.4 & 59.2 & 60.4 & 6.8 & 6.4 & 0.830 & 0.837 & 9.4 & 9.2 \\
\hline & $\pm 1.3^{\mathrm{b}, 1}$ & $\pm 1.5^{\mathrm{c}, 1}$ & $\pm 1.3^{a, 1}$ & $\pm 1.4^{a b, 1}$ & $\pm 0.6^{c, 1}$ & $\pm 0.8^{d, 1}$ & $\pm 0.004^{b, 1}$ & $\pm 0.004^{b, 2}$ & $\pm 0.7^{b, 1}$ & $\pm 0.5^{\mathrm{ab}, 1}$ \\
\hline
\end{tabular}

\subsection{Active properties}

\subsubsection{ANTIMICROBIAL PROPERTIES}

Microbial counts obtained for protein solutions and films in the in vitro assays are shown in

Table 4. As concerns the protein solutions, no notable reduction in the growth of L.innocua with respect to the control was observed at either $10^{\circ} \mathrm{C}$ or $25^{\circ} \mathrm{C}$, since only a small, but significant, reduction was detected at $25^{\circ} \mathrm{C}$ for $\mathrm{LF}$ with respect to the control sample. However, the mixture of both proteins resulted in a significant reduction in the growth of inoculated E.coli; at both tested temperatures. The application of both proteins resulted in a synergistic action against the gramnegative bacteria E.coli, which led to a decimal reduction of 1.3 and 1.9 at 10 and $25^{\circ} \mathrm{C}$, respectively. Barbiroli et al. (2012) observed similar behavior by applying both proteins against E.coli. The ability of the LF to increase the outer membrane's permeability can facilitate the access of LZ to the peptidoglycan in the inner cell membrane. Nevertheless, no reduction in the growth of either bacterium was observed when LF and LZ were included in the PS films, probably due to the relatively weak activity detected in the proteins and the fact that their diffusion to the cells was hindered by the interactions with starch chains in the film matrix (section 3.2). In this sense, it is remarkable that counts in samples coated with protein-free starch films were significantly higher than in the uncoated control 
sample, which reveals that the starch support can act as an effective nutrient for bacteria, while inhibiting the protein diffusion to the culture medium.

TABLE 4. Microbial counts of L.innocua and E.coli after a period of incubation of $24 \mathrm{~h}$ at $10^{\circ} \mathrm{C}$ and $25^{\circ} \mathrm{C}$ on TSA-NaCl medium for pure protein solutions and films. Mean values and standard deviations of $\log \mathrm{CFU} / \mathrm{cm}^{2}$.

\begin{tabular}{c|c|cc|cc}
\hline \multicolumn{2}{c|}{ Formulation } & \multicolumn{2}{c|}{ L.innocua } & \multicolumn{2}{c}{ E.coli } \\
\hline \multirow{4}{*}{ Protein solution } & Control & $2.6 \pm 0.3^{\mathrm{ab}}$ & $6.9 \pm 0.3^{\mathrm{b}}$ & $3.57 \pm 0.09^{\mathrm{b}}$ & $7.73 \pm 0.19^{\mathrm{d}}$ \\
\cline { 2 - 6 } & $\mathrm{LF}$ & $2.4 \pm 0.2^{\mathrm{ab}}$ & $6.41 \pm 0.08^{\mathrm{a}}$ & $3.41 \pm 0.04^{\mathrm{b}}$ & $7.1 \pm 0.2^{\mathrm{b}}$ \\
\cline { 2 - 6 } & $\mathrm{LZ}$ & $2.25 \pm 0.04^{\mathrm{a}}$ & $6.8 \pm 0.3^{\mathrm{b}}$ & $3.52 \pm 0.09^{\mathrm{b}}$ & $7.41 \pm 0.14^{\mathrm{c}}$ \\
\cline { 2 - 6 } & LF-LZ & $2.60 \pm 0.09^{\mathrm{b}}$ & $6.86 \pm 0.14^{\mathrm{b}}$ & $2.3 \pm 0.2^{\mathrm{a}}$ & $5.86 \pm 0.02^{\mathrm{a}}$ \\
\hline \multirow{4}{*}{ Films } & Control & $2.5 \pm 0.2^{\mathrm{a}}$ & $6.91 \pm 0.14^{\mathrm{a}}$ & $2.15 \pm 0.05^{\mathrm{a}}$ & $7.18 \pm 0.17^{\mathrm{bc}}$ \\
\cline { 2 - 6 } & $0-0$ & $2.8 \pm 0.3^{\mathrm{b}}$ & $7.32 \pm 0.10^{\mathrm{cd}}$ & $2.90 \pm 0.06^{\mathrm{e}}$ & $6.88 \pm 0.10^{\mathrm{a}}$ \\
\cline { 2 - 6 } & $0.2-0$ & $2.90 \pm 0.09^{\mathrm{b}}$ & $7.07 \pm 0.11^{\mathrm{b}}$ & $2.33 \pm 0.05^{\mathrm{b}}$ & $6.83 \pm 0.07^{\mathrm{a}}$ \\
\cline { 2 - 6 } & $0-0.2$ & $2.87 \pm 0.08^{\mathrm{b}}$ & $7.34 \pm 0.07^{\mathrm{d}}$ & $2.51 \pm 0.05^{\mathrm{b}}$ & $7.31 \pm 0.05^{\mathrm{c}}$ \\
\cline { 2 - 6 } & $0.1-0.1$ & $2.86 \pm 0.07^{\mathrm{b}}$ & $7.17 \pm 0.07^{\mathrm{bc}}$ & $2.43 \pm 0.03^{\mathrm{c}}$ & $7.04 \pm 0.04^{\mathrm{b}}$ \\
\hline
\end{tabular}

Different letters $(a, b, c, d)$ in the same column indicate significant differences among the different formulations for the same bacterium and

Accordingly, when films with and without proteins were applied to minced meat (Figure 7), no notable antimicrobial activity was observed, since no significant differences $(p<0.05)$ in the counts of total aerobic meat bacteria of the different samples were found after 15 incubation days. Both proteins and their mixtures embedded in the films were ineffective against the natural aerobic microbiota of minced meat pork. However, in samples coated with films containing both proteins $(0.1-0.1)$, the coliform counts after 14 incubation days showed a reduction of about $1 \mathrm{log}$, with respect to the samples coated with the control film (without proteins). As observed in the in vitro test, samples coated with the control film exhibited higher coliform counts than uncoated samples. The results agree with what was observed in in vitro assay, with respect to the nutritive role of the starch support for bacteria and the synergistic action against Gram-negative bacteria of combined proteins. Neither LF nor LZ were effective enough when they were applied separately, but a weakly enhanced antimicrobial activity against $E$.coli and coliform microbiota of pork meat was observed when they were combined. 

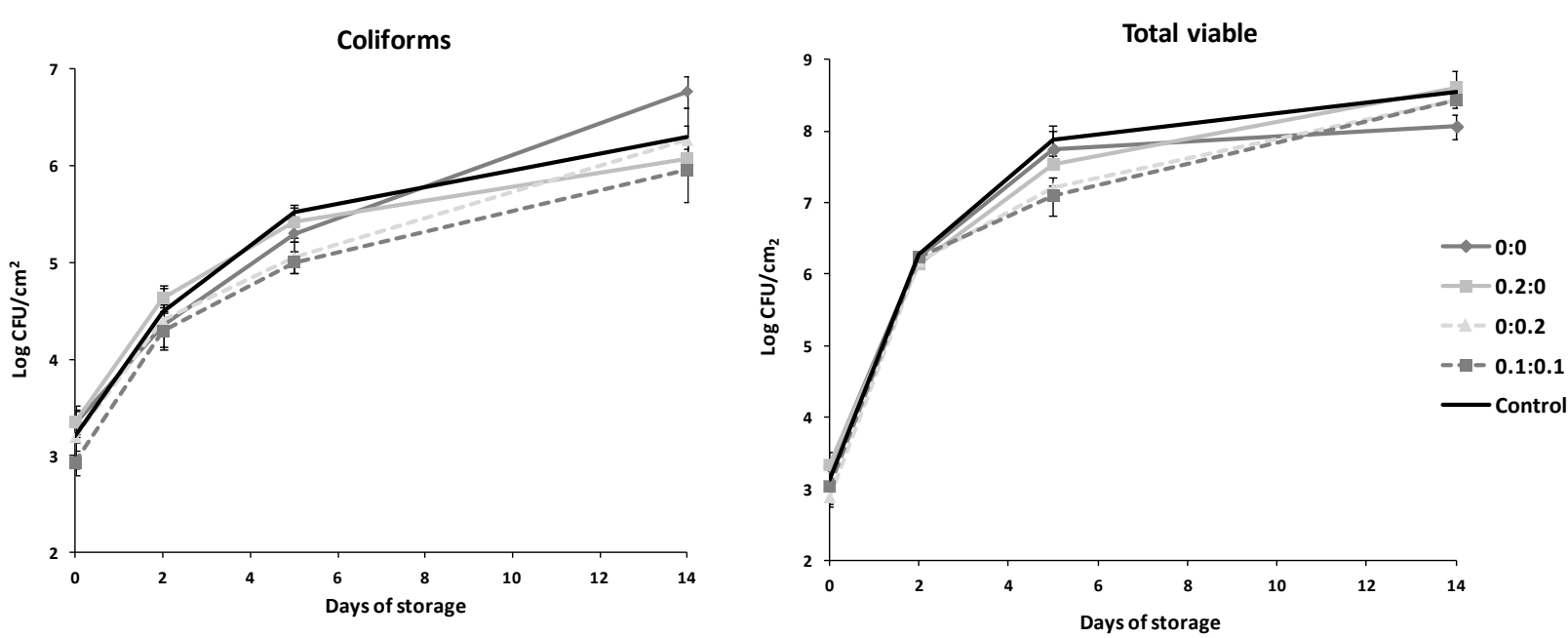

FIGURE 7. Microbial counts of minced pork meat samples coated with PS based edible films containing $L F$ and/or $L Z$ as a function of storage time at $10{ }^{\circ} \mathrm{C}$. Mean values and standard deviation. Control $=$ non-coated samples.

\subsubsection{ANTIOXIDANT PROPERTIES}

The antioxidant capacity of proteins, expressed as TEAC value (trolox equivalent antioxidant capacity) in g protein/L was $13.2 \pm 0.7,15.3 \pm 0.4$ and $15.4 \pm 0.6$, respectively for $L F, L Z$ and their blend. So, the antioxidant activity of LF was significantly higher than those obtained for LZ and the LF-LZ blend $(p<0.05)$. LF has previously been pointed out as a protein with antioxidant ability, mainly due to its strong chelation capacity of transition metals. Therefore, its use as a natural antioxidant preservative in food has great potential (Stejins and Hooijdonk, 2000). LZ showed lower antioxidant ability than LF $(p<0.05)$, but it was high enough for $L Z$ to be considered as a natural antioxidant compound. No synergistic activity between either protein was observed for the LF-LZ mixture.

Figure 8 shows peroxide values of lard samples, both uncoated and coated with the films, after differing storage times. Low PV values, with no significant differences among the samples, were obtained after relatively short storage periods. Nevertheless, they increased considerably after long storage times. In this case, significant differences were observed for both uncoated and coated samples. This can be attributed to the low oxygen permeability of the films (Table 2), which inhibits the oxygen reactions with the substrate. Among the samples coated with the different films, the highest 


\section{PV}

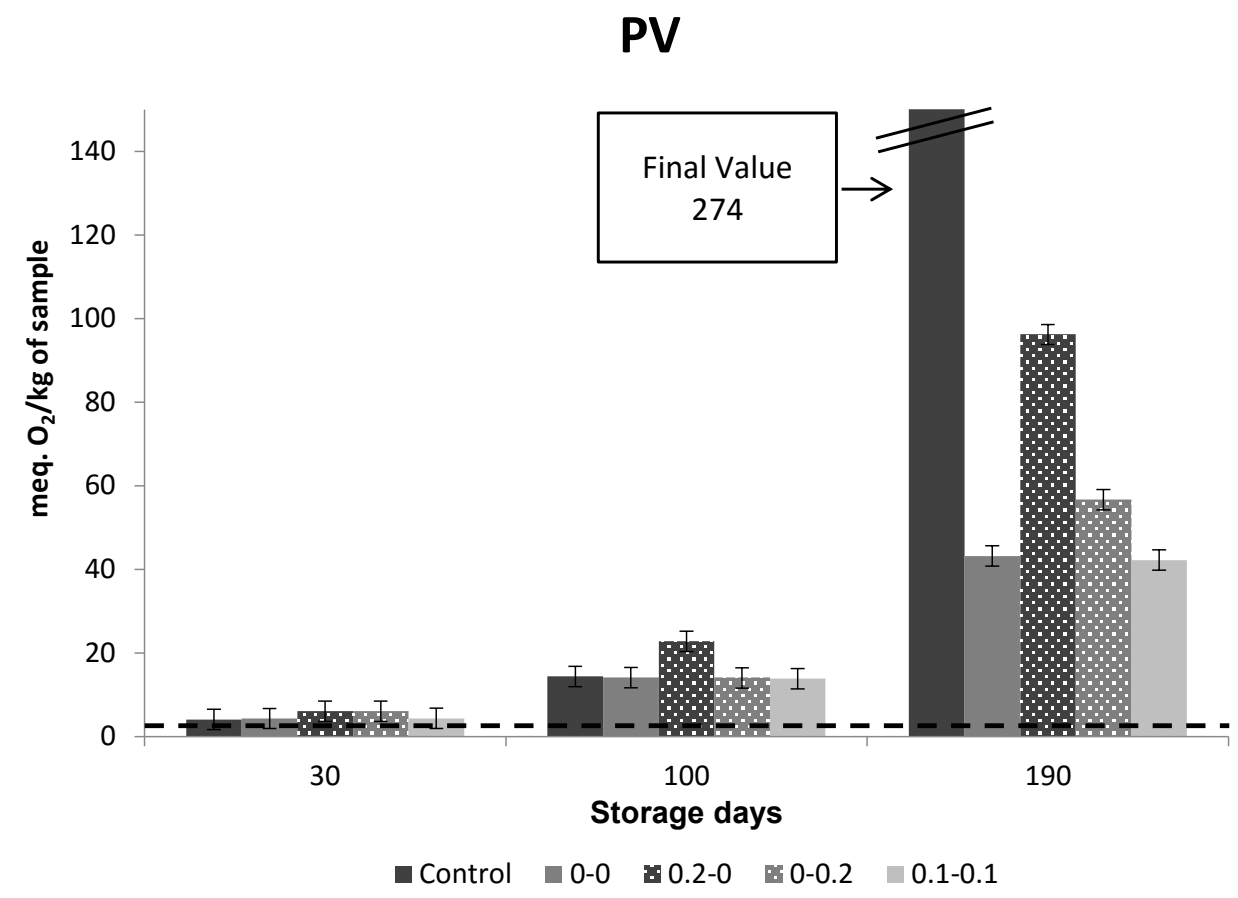

FIGURE 8. Peroxide value (PV) of fat samples coated with PS based edible films containing LF and/or LZ at different storage times at $40^{\circ} \mathrm{C}$ and $53 \% \mathrm{RH}$. Mean values and $95 \% \mathrm{LSD}$ intervals. Control $=$ non-coated samples. Dashed line corresponds to the PV initial value of the fat.

OP value was obtained for the films containing $0.2 \mathrm{~g} \mathrm{LF} / \mathrm{g}$ starch, despite the fact that the highest antioxidant activity was found for LF in the TROLOX test. This could be due to the inherent iron content of LF which could promote oxidation reactions at high concentrations of the protein, as reported by Nielsen et al., (2004).

\section{Conclusion}

The incorporation of antimicrobial proteins (lactoferrin and/or lysozyme) had an impact on the structural and physical properties of potato starch films and affected their thermal behaviour by increasing the glass transition temperature. Both proteins showed a certain degree of compatibility with starch chains through the bond formations which increased the Tg values, while a part separates and migrates to the film surface, there giving rise to globular heterogeneous formations. The incorporation of proteins, especially lactoferrin, greatly increased the film's brittleness, regardless of the film's water content, although they enhanced the water vapour and oxygen barrier properties. The protein also reduced the film's transparency and gloss, while lactoferrin induced colour changes, associated with its selective light absorption. The thermal degradation of blend films and isolated proteins occurred at temperatures of over $250^{\circ} \mathrm{C}$, which means that starch-protein blends can be thermoprocessed according to the starch's thermoplastic properties and following the usual practices of the plastics industries. The films containing a blend of lactoferrin and lysozyme reduced the total coliform counts in minced pork meat, but did not show significant antimicrobial activity against $\mathrm{L}$. innocua and E. coli. Nevertheless, all the films were effective at reducing lard oxidation after long storage times. Studies into the release kinetics of the bioactive proteins or peptides in food systems 
are required to establish the usefulness of both LF and LZ in developing biodegradable and bioactive packaging materials.

654

655

656

657

658

659

660

661

662

663

664

665

666

\section{Acknowledgements}

The authors acknowledge the financial support provided by the Generalitat Valenciana (GV/2013/152) and Ministerio de Economía y Competividad (Projects AGL2013-42989-R) and the services rendered by the Electron Microscopy Service of the UPV. Olga Moreno Marro also thanks the Ministerio de Educación, Cultura y Deporte for the FPU 2012-1121 grant.

\section{References}

Arnold, R. R., \& Cole, M. F. (1977). A bactericidal effect for human lactoferrin. Science, 197(4300), 263-265.

Atarés, L., Bonilla, J., \& Chiralt, A. (2010). Characterization of sodium caseinate-based edible films incorporated with cinnamon or ginger essential oils. Journal of Food Engineering, 100(4), 678-687.

ASTM. (1995). Standard test methods for water vapour transmission of materials. In Standard designations: E96-95 annual book of ASTM standards. Philadelphia, PA: American Society for Testing and Materials.

ASTM. (1999). Standard test methods for specular gloss. Designation (D523): Annualbook of ASTM standards (Vol. 06.01) Philadelphia, PA: American Society for Testing and Materials.

ASTM. (2001). Standard test method for tensile properties of thin plastic sheeting. In Standard D882 annual book of American Standard Testing Methods. Philadelphia,PA: American Society for Testing and Materials. ASTM.

ASTM. (2005). Standard test method for oxygen gas transmission rate through plasticfilm and sheeting using a coulometric sensor. In Standard designation: D3985-05:annual book of American Society for Testing Materials. West Conshohocken, PA: ASTM.

Azeredo, H. M. C. d. (2009). Nanocomposites for food packaging applications. Food Research International, 42(9), 1240-1253.

Barbiroli, A., Bonomi, F., Capretti, G., lametti, S., Manzoni, M., Piergiovanni, L., et al. (2012). Antimicrobial activity of lysozyme and lactoferrin incorporated in cellulose-based food packaging. Food Control,26 (2), 387-392.

Barnett, I., (2012). Packaging Solutions Throughout the Supply Chain: Technology, Trends and Future Outlook. Business Insight, London. 

activities by ethylendiaminetetraacetic acid and lactoferrin. International Journal of Food Microbiology, 90, 63-74.

Buonocore, G.G., Conte, A., Corbo, M.R., Sinigaglia, M., Del Nobile, M.A., (2005). Monoand multilayer active films containing lysozyme as antimicrobial agent. Innovative Food Science and Emerging Technologies 6, 459-464.

Byun, Y., \& Kim, Y. T. (2014). Chapter 14 - bioplastics for food packaging: Chemistry and physics. In J. H. Han (Ed.), Innovations in food packaging (second edition) (pp. 353-368). San Diego: Academic Press.

Cano, A., Jiménez, A., Cháfer, M., Gónzalez, C., \& Chiralt, A. (2014). Effect of amylose:Amylopectin ratio and rice bran addition on starch films properties. Carbohydrate Polymers, 111(0), 543-555.

Corradini, C., Alfieri, I., Cavazza, A., Lantano, C., Lorenzi, A., Zucchetto, N., et al. (2013). Antimicrobial films containing lysozyme for active packaging obtained by sol-gel technique. Journal of Food Engineering, 119(3), 580-587.

Corrales, M., Fernández, A., \& Han, J. H. (2014). Chapter 7 - antimicrobial packaging systems. In J. H. Han (Ed.), Innovations in food packaging (second edition) (pp. 133-170). San Diego: Academic Press

Das, D.K., Dutta, H., Mahanta, C.L., 2013. Development of a rice starch-based coating with antioxidant and microbe-barrier properties and study of its effect on tomatoes stored at room temperature. LWT_Food Science Technology. 50, 272-278.

Drago, M.E. (2006). Actividades antibacterianas de lactoferrina. Enfermedades Infecciosas y Microbiología, 26 (2), 58-63.

Elias, R. J., Kellerby, S. S., \& Decker, E. A. (2008). Antioxidant activity of proteins and peptides. Critical Reviews in Food Science and Nutrition, 48(5), 430-441.

Ellison, R. D., Giehl, T. J., \& LaForce, F. M. (1988). Damage of the outer membrane of enteric gramnegative bacteria by lactoferrin and transferrin. Infection and Immunity, 56(11), 2774-2781.

Farahnaky, A., Farhat, I. A., Mitchell, J. R., \& Hill, S. E. (2009). The effect of sodium chloride on the glass transition of potato and cassava starches at low moisture contents. Food Hydrocolloids, 23(6), 1483-1487.

Farnaud, S., \& Evans, R. W. (2003). Lactoferrin—a multifunctional protein with antimicrobial properties. Molecular Immunology, 40(7), 395-405.

García-Montoya, I. A., Cendón, T. S., Arévalo-Gallegos, S., \& Rascón-Cruz, Q. (2012). Lactoferrin a multiple bioactive protein: An overview. Biochimica Et Biophysica Acta (BBA) - General Subjects, 1820(3), 226-236. 
Gemili, S., Yemenicioglu, A., Altınkaya, S.A., (2009). Development of cellulose acetate based antimicrobial food packaging materials for controlled release of lysozyme. Journal of Food Engineering 90, 453-462.

Gill, A. O., \& Holley, R. A. (2000). Inhibition of bacterial growth on ham and bologna by lysozyme, nisin and EDTA. Food Research International, 33, 83-90.

Gimenez, B., Gomez-Guillen, M.C., Perez-Mateos, M., Montero, P., Marquez-Ruiz, G., 2011. Evaluation of lipid oxidation in horse mackerel patties covered with boragecontaining film during frozen storage. Food Chemistry. 124, 1393-1403.

González-Chávez, S. A., Arévalo-Gallegos, S., \& Rascón-Cruz, Q. (2009). Lactoferrin: structure, function and applications. International journal of antimicrobial agents, 33(4), 301-e1.

Güçbilmez, Ç. M., Yemenicioğlu, A., \& Arslanoğlu, A. (2007). Antimicrobial and antioxidant activity of edible zein films incorporated with lysozyme, albumin proteins and disodium EDTA. Food Research International, 40(1), 80-91.

Gyawali, R., \& Ibrahim, S. A. (2014). Natural products as antimicrobial agents. Food Control, 46(0), 412429.

Han, J. H., Seo, G. H., Park, I. M., Kim, G. N., \& Lee, D. S. (2006). Physical and mechanical properties of pea starch edible films containing beeswax emulsions. Journal of Food Science, 71(6), E290-E296.

Han, J.H., Hwang, H.-M., Min, S., Krochta, J.M., 2008. Coating of peanuts with edible whey protein film containing $\alpha$-tocopherol and ascorbyl palmitate. Journal of Food Science. 73, 1750-3841.

He, Y., Kong, W., Wang, W., Liu, T., Liu, Y., Gong, Q., et al. (2012). Modified natural halloysite/potato starch composite films. Carbohydrate Polymers, 87(4), 2706-2711.

Huang, D., Ou, B., \& Prior, R. L. (2005). The chemistry behind antioxidant capacity assays. Journal of Agricultural and Food Chemistry, 53(6), 1841-1856.

Hutchings, J. B. (1999). Food and colour appearance (2nd ed.). Gaithersburg, MD:Chapman and Hall Food Science Book, Aspen Publication.

Jenssen, H., \& Hancock, R. E. W. (2009). Antimicrobial properties of lactoferrin. Biochimie, 91(1), 19-29.

Jiménez, A., Fabra, M. J., Talens, P., \& Chiralt, A. (2012). Effect of re-crystallization on tensile, optical and water vapour barrier properties of corn starch films containing fatty acids. Food Hydrocolloids, 26(1), 302310.

Jiménez, A., Fabra, M. J., Talens, P., \& Chiralt, A. (2013). Phase transitions in starch based films containing fatty acids. effect on water sorption and mechanical behaviour. Food Hydrocolloids, 30(1), 408-418. 
Joubran, Y., Mackie, A., \& Lesmes, U. (2013). Impact of the Maillard reaction on the antioxidant capacity of bovine lactoferrin. Food chemistry, 141(4), 3796-3802.

Kaur, B., Ariffin, F., Bhat, R., \& Karim, A. A. (2012). Progress in starch modification in the last decade. Food Hydrocolloids, 26(2), 398-404.

Kechichian, V., Ditchfield, C., Veiga-Santos, P., \& Tadini, C. C. (2010). Natural antimicrobial ingredients incorporated in biodegradable films based on cassava starch. LWT - Food Science and Technology, 43(7), 1088-1094.

Kristo, E., Koutsoumanis, K. P., \& Biliaderis, C. G. (2008). Thermal, mechanical and water vapor barrier properties of sodium caseinate films containing antimicrobials and their inhibitory action on Listeria monocytogenes. Food Hydrocolloids, 22(3), 373-386.

Lee, D. S. (2014). Chapter 6 - antioxidative packaging system. In J. H. Han (Ed.), Innovations in food packaging (second edition) (pp. 111-131). San Diego: Academic Press.

Lin, L., Wang, B., Wang, M., Cao, J., Zhang, J., Wu, Y., et al., 2008. Effects of a chitosan-based coating with ascorbic acid on post-harvest quality and core browning of 'Yali' pears (Pyrus bertschneideri Rehd.). Journal of the Science of Food and Agriculture. 88, 877-884.

Liu, H., Zheng, F., Cao, Q., Ren, B., Zhu, L., Striker, G., \& Vlassara, H. (2006). Amelioration of oxidant stress by the defensin lysozyme. American Journal of Physiology-Endocrinology and Metabolism, 290(5), 824-832.

Ma, X., Chang, P. R., \& Yu, J. (2008). Properties of biodegradable thermoplastic pea starch/carboxymethyl cellulose and pea starch/microcrystalline cellulose composites. Carbohydrate Polymers, 72(3), 369-375.

Mc Hugh, T. H., Avena-Bustillos, R., \& Krochta, J. M. (1993). Hydrophobic edible films: modified procedure for water vapor permeability and explanation of thickness effects. Journal of Food Science, 58(4), 899-903.

Monedero, F. M., Fabra, M. J., Talens, P., \& Chiralt, A. (2010). Effect of calcium and sodium caseinates on physical characteristics of soy protein isolate-lipid films. Journal of Food Engineering, 97(2), 228-234.

Moreira, M. R., Ponce, A. G., Del Valle, C. E., \& Roura, S. I. (2005). Inhibitory parameters of essential oils to reduce a foodborne pathogen. LWT - Food Science and Technology, 38, 565-570.

Moreno, O., Pastor, C., Muller, J., Atarés, L., González, C., Chiralt., A. (2014). Physical and bioactive properties of corn starch - Buttermilk edible films. Journal of Food Engineering 141, 27-36.

Nielsen, N. S., Petersen, A., Meyer, A. S., Timm-Heinrich, M., \& Jacobsen, C. (2004). Effects of lactoferrin, phytic acid and EDTA on oxidation in two food emulsions enriched with long-chain polyunsaturated fatty acids. Journal of Agricultural and Food Chemistry, 52(25), 7690-7699. 
Pan, Y., Shiell, B., Wan, J., Coventry, M. J., Roginski, H., Lee, A., et al. (2007). The molecular characterisation and antimicrobial activity of amidated bovine lactoferrin. International Dairy Journal, 17(6), 606-616.

Pastor, C., Sánchez-González, L., Cháfer, M., Chiralt, A., \& González-Martínez, C. (2010). Physical and antifungal properties of hydroxypropylmethylcellulose based films containing propolis as affected by moisture content. Carbohydrate Polymers, 82(4), 1174-1183.

Pyla, R., Kim, T., Silva, J. L., \& Jung, Y. (2010). Enhanced antimicrobial activity of starch-based film impregnated with thermally processed tannic acid, a strong antioxidant. International Journal of Food Microbiology, 137(2-3), 154-160.

Re, R., Pellegrini, N., Proteggente, A., Pannala, A., Yang, M., \& Rice-Evans, C. (1999). Antioxidant activity applying an improved ABTS radical cation decolorization assay. Free radical biology and medicine, 26(9), 1231-1237.

Realini, C. E., \& Marcos, B. (2014). Active and intelligent packaging systems for a modern society. Meat Science, 98(3), 404-419.

Reyes, R. E., Manjarrez, H. A., \& Drago, M. E. (2005). El hierro y la virulencia bacteriana. Enfermedades Infecciosas y Microbiología, 25, 104-7.

Samarasinghe, R. M., Kanwar, R. K., \& Kanwar, J. R. (2014). The effect of oral administration of iron saturated-bovine lactoferrin encapsulated chitosan-nanocarriers on osteoarthritis. Biomaterials, 35(26), $7522-7534$

Sánchez-García, M.D., Giménez, E., \& Lagaron, J.M. (2008). Morphology and barrier properties of solvent cast composites of thermoplastic biopolymers and purified cellulose fibers. Carbohydrate Polymers 71, 235244.

Sánchez-González, L., Cháfer, M., Hernández, M., Chiralt, A., \& González-Martínez, C. (2011). Antimicrobial activity of polysaccharide films containing essential oils. Food Control, 22(8), 1302-1310.

Soares, R. M. D., Lima, A. M. F., Oliveira, R. V. B., Pires, A. T. N., \& Soldi, V. (2005). Thermal degradation of biodegradable edible films based on xanthan and starches from different sources. Polymer Degradation and Stability, 90(3), 449-454.

Steijns, J. M., \& Van Hooijdonk, A. C. M. (2000). Occurrence, structure, biochemical properties and technological characteristics of lactoferrin. British Journal of Nutrition, 84(S1), 11-17. 
Sung, S. Y., Sin, L. T., Tee, T. T., Bee, S. T., Rahmat, A. R., Rahman, W. A. W. A., .. \& Vikhraman, M. (2013). Antimicrobial agents for food packaging applications. Trends in Food Science \& Technology, 33(2), 110-123.

Suzuki, T., Yamauchi, K., Kawase, K., Tomita, M., Kiyosawa, I., \& Okonogi, S. (1989). Collaborative bacteriostatic activity of bovine lactoferrin with lysozyme against Escherichia coli 0111. Agricultural and biological chemistry, 53(6), 1705-1706.

Wakabayashi, H., Yamauchi, K., \& Takase, M. (2006). Lactoferrin research, technology and applications. International Dairy Journal, 16(11), 1241-1251.

Wilhelm, H. -., Sierakowski, M. -., Souza, G. P., \& Wypych, F. (2003). Starch films reinforced with mineral clay. Carbohydrate Polymers, 52(2), 101-110.

Yamauchi, K. (1992). Biologically functional proteins of milk and peptides derived from milk proteins. Bulletin of the International Dairy Federation, 272, 51-58.

Zhang, Y., Rempel, C., \& McLaren, D. (2014). Chapter 16 - thermoplastic starch. In J. H. Han (Ed.), Innovations in food packaging (second edition) (pp. 391-412). San Diego: Academic Press. 